\title{
A new multifactorial approach for studying intraannual secondary growth dynamics in Mediterranean mixed forests: Integrating biotic and abiotic interactions.
}

\begin{tabular}{|c|c|}
\hline Journal: & Canadian Journal of Forest Research \\
\hline Manuscript ID & cjfr-2017-0139.R3 \\
\hline Manuscript Type: & Article \\
\hline Date Submitted by the Author: & 30-Dec-2017 \\
\hline Complete List of Authors: & $\begin{array}{l}\text { de-Dios-García, Javier; Instituto Nacional de Investigacion y Tecnologia } \\
\text { Agraria y Alimentaria, Forest research centre. Department of Silviculture } \\
\text { and management of forest systems; Centre Tecnologgic Forestal de } \\
\text { Catalunya, FiDBosc } \\
\text { Manso, Rubén; INRA, LERFoB; Forestry Commission, Forest Research. } \\
\text { Northern Research Station } \\
\text { Calama, Rafael; CIFOR-INIA } \\
\text { Fortin, Mathieu; INRA, AgroParisTech } \\
\text { Pardos, Marta; CIFOR-INIA, }\end{array}$ \\
\hline Keyword: & $\begin{array}{l}\text { Dendrometers, Mixed stands, Climate change, Non-linear mixed model, } \\
\text { Mediterranean species }\end{array}$ \\
\hline $\begin{array}{r}\text { Is the invited manuscript for } \\
\text { consideration in a Special } \\
\text { Issue? : }\end{array}$ & N/A \\
\hline
\end{tabular}


1 A new multifactorial approach for studying intraannual secondary growth dynamics in 2 Mediterranean mixed forests: Integrating biotic and abiotic interactions.

3

4 Javier de-Dios-García ${ }^{1,2}$, Rubén Manso ${ }^{3,4}$, Rafael Calama ${ }^{1}$, Mathieu Fortin ${ }^{3}$, Marta Pardos ${ }^{1}$ 5

${ }^{1}$ Department of Silviculture and management of forest systems, INIA-Forest research centre, Ctra. de la Coruña km 7.5, Madrid, 28040, 7 Spain.

$8 \quad{ }^{2}$ Forest Sciences Centre of Catalonia (CTFC). Ctra. Sant Llorenç, km. 2, 25280, Solsona, Spain.

$9{ }^{3}$ Laboratoire d'Etude de Ressources Forêt-Bois (LERFoB UMR 1092), INRA/AgroParisTech., 14 rue Girardet, Nancy Cedex, F-54042, 10 France.

${ }^{4}$ Forest Research. Northern Research Station. Roslin, Midlothian, EH25 9SY, UK.

13 mathieu.fortin@agroparistesch.fr.

14 Corresponding author: Javier de-Dios-García. Tel.: +34 9734817 52; Fax: +34 9734804 31; Email: javierdediosgarcia@gmail.com. 


\section{Abstract}

Studying intraannual growth dynamics through a modelling approach has proved useful for characterizing differences in wood phenology between species and deviations from the expected tree growth due to climate change. The aim of this paper was to determine the climatic factors and the inter- and intraspecific competition traits that drive intraannual secondary growth dynamics in three Mediterranean tree species that naturally coexist in the Spanish Northern plateau (Pinus pinea, Juniperus thurifera and Quercus ilex). For this purpose we obtained girth increment data from band dendrometers installed on 58 trees from May 2012 to April 2015. Half of them were located in a highdensity plot and half in a low-density plot. These data were analysed through a non-linear multifactorial model considering daily and cumulative climatic effects together with inter- and intraspecific competition indices. Our results provide evidence of a spatio-temporal niche separation between species. Compared to other species, $Q$. ilex showed a wider thermal amplitude, a higher mean optimum temperature for growth and a milder effect of drought on its secondary growth. Under current climate change projections, simulations based on our model predict a secondary growth reduction for $P$. pinea and a growth enhancement for $Q$. ilex in these Mediterranean mixtures.

\section{Keywords}

Dendrometers; Mixed stands; Climate change; Non-linear mixed models; Mediterranean species; 


\section{Introduction}

Mixed-species forests have gained significant attention in recent years as many studies have shown that tree species richness is a key feature for most forest functions and services (Río et al. 2016). Some studies have stressed the role of certain mixtures in the improvement of individual tree resistance and resilience (e.g. Lebourgeois et al., 2013). These benefits are not observed neither in all forest types, nor for all tree species (Grossiord et al. 2014, Merlin et al. 2015) but they are expected to be more frequent in drought-prone sites (Pretzsch et al. 2013) like Mediterranean forests. However it remains unclear how global change will modify mixed forests dynamics in the Mediterranean basin.

Global warming is known to alter plant phenology (Cleland et al. 2007) leading to decreases in tree radial growth in some cases (Lebourgeois et al. 2010, Natalini et al. 2015). The analysis of intraannual growth dynamics through a modelling approach has proved useful for characterizing differences in wood phenology between species and deviations from the expected tree growth due to climate change (Michelot et al. 2012). Although height growth patterns tend to be similar between coexisting tree species, this does not apply to diameter growth. Carbon assimilated by trees through photosynthesis is firstly assigned to build new photosynthetic tissues (Gea-Izquierdo et al. 2009) and primary growth, and only remaining carbohydrates are allocated to girth increment. During the growing season the timing, duration and rate of radial growth can change among species (Rossi et al. 2006) and may also change through species interactions and with varying climatic conditions.

The role of competition restraining individual tree growth has been widely discussed in the forestry literature, mainly by the use of competition indices. Recent studies have addressed this issue studying the role of inter- and intraspecific interactions on interannual growth (Manso et al. 2015, De-DiosGarcía et al. 2015). However understanding how these inter- and intraspecific interactions affect seasonal or daily tree growth in mixtures remains a challenge.

Studies on intraannual growth dynamics have been performed using manual band dendrometers (Martín et al. 2014), automatic band dendrometers (Urban et al. 2013), electronic point dendrometers (Zweifel et al. 2006) and core (Delpierre et al. 2016) or microcore extraction (Rossi et al. 2006). In spite of their low resolution on a daily basis, advantages from manual band dendrometers are related to their low cost of installation and maintenance (McMahon and Parker 2015) which allows to carry out 
measurements over a larger sample of trees and during longer time spans. These methods are more accurate for analysing the radial growth of the whole stem than invasive techniques like core or microcore extraction and electronic point dendrometers, which can be affected by local changes in the xylem or the bark (Gutiérrez et al. 2011).

Despite the widespread use of band dendrometers for assessing intraannual growth patterns, most studies have focussed on defining patterns of seasonal dynamics and growth phenology (Urban et al. 2013), with only a few studies aiming to gain insight into the factors driving differences in intraannual growth between trees, sites and species (McMahon and Parker 2015).

The effect of climatic factors on intraannual growth has usually been evaluated by means of univariate analysis, such as Pearson's correlation coefficient (Grogan and Schulze 2012) or univariate regression models, which focus on an assumed linear relation among the studied effect and a single factor at each time. However, understanding the effect of multiple factors as well as their complex interactions on growth should be approached through more complex multivariate and non-linear models (Paine et al. 2012).

Our aim was to determine the climatic factors and the inter- and intraspecific competition traits that drive intraannual secondary growth dynamics in three Mediterranean tree species, Pinus pinea L., Quercus ilex subsp. ballota (Desf.) Samp., and Juniperus thurifera L., co-occurring in mixed forests in the Spanish Northern Plateau, by means of a modelling approach. The specific objectives of this analysis were (a) to determine the competition factors that define the daily potential secondary growth of the subject tree; (b) to elucidate the main climatic factors that limit the daily potential girth increment for each tree species coexisting in $P$. pinea mixed stands. Our first hypothesis was that the effect of inter- and intraspecific competition on potential growth would be different for each species, $P$. pinea being more competitive than $J$. thurifera and $Q$. ilex subsp. ballota both with conspecific trees and with the other tree species (De-Dios-García et al. 2015). In line with other studies (Mayoral et al. 2015) our second hypothesis was that $Q$. ilex subsp. ballota (hereafter $Q$. ilex) would reach its optimum growth conditions at higher temperatures than $P$. pinea and $J$. thurifera. Our third hypothesis was that $Q$. ilex would be more tolerant to summer drought than the other tree species (Mayoral et al. 
2015), achieving higher girth increments in relative terms than $P$. pinea and $J$. thurifera during the dry season.

\section{Material and methods}

\subsection{Data collection}

\subsubsection{Study area}

The study area is located in the Carrascal state forest $\left(41^{\circ} 36^{\prime} \mathrm{N}, 4^{\circ} 19^{\prime} \mathrm{W}\right)$, in a flat zone within the limestone plain areas in the east of the province of Valladolid, in the Spanish Northern Plateau. The elevation is around $885 \mathrm{~m}$, the average annual precipitation is highly variable ranging from 220 to 630 mm and it mainly falls during autumn and spring. The mean annual temperature is $11{ }^{\circ} \mathrm{C}$, reaching maximum average values of $37{ }^{\circ} \mathrm{C}$ in the warmest months (July and August) and minimum average values of $-5{ }^{\circ} \mathrm{C}$ in the coldest ones (December and January), according to historical data (1975-2010) from Valladolid meteorological station (www.aemet.com). The area has a Mediterranean continental climate with a characteristic hot and dry summer period during which mean monthly precipitation is $21 \mathrm{~mm}$. The main types of soils are inceptisols with an average water holding capacity of $176 \mathrm{~mm} / \mathrm{m}$. In the province of Valladolid, $P$. pinea occupies 74000 ha (29 000 ha are pure stands, 33000 are mixed stands with other conifers and 12,000 ha are mixed stands with hardwoods). Mixed stands with hardwoods represent the most diverse and complex forest systems in the region and are mainly located in limestone plain areas. The present study focused on these more complex admixtures, where Pinus pinea grows with Quercus ilex and Juniperus thurifera.

Land ownership has played a critical role in the maintenance of mixed broadleaf-conifer forests in the Spanish Northern Plateau, where $P$. pinea, $P$. pinaster, $Q$. ilex, $Q$. faginea and $J$. thurifera naturally coexist. Nowadays most of these structurally complex admixtures are found on land that was privately owned until the 1980s. The lack of investments from private owners and the absence of management plans contributed to the preservation of these mixtures. Most of this land was sold to the regional government in the 1980s. At that time, management in mixtures began to focus on a tree selection system, promoting growth and regeneration of all tree species. Conservation of biodiversity is the main management objective in these forests, together with other ecosystem services such as cone and nut production, timber and biomass, mushrooms and recreational uses. 


\subsubsection{Experimental design-dendrometer measurements}

Data were collected from two adjacent $50 \mathrm{~m}$ x $60 \mathrm{~m}$ plots placed in two contrasting stocking densities: A high density plot (basal area $\mathrm{G}=18.8 \mathrm{~m}^{2} / \mathrm{ha}$ ), which is located in a wildlife corridor that has not been managed since the 1970 s and a low density plot (basal area $G=9.6 \mathrm{~m}^{2} / \mathrm{ha}$ ), where the last forest management intervention was carried out in 2002. Within each plot, the coordinates of all trees with height greater than $1.30 \mathrm{~m}$ were recorded during the summer of 2011. During that measurement as well as in the subsequent measurements, diameter at breast height (dbh), stump diameter, total height, height to crown base, and four perpendicular crown radii measured in cardinal directions were recorded for each tree. Stand attributes are shown in Table 1.

Intraannual girth increment was measured by means of band dendrometers (Dendrometer Increment Sensor DB20 EMS Brno, (www.emsbrno.cz), which were mounted at breast height $(1.30 \mathrm{~m})$ on 58 trees $(\mathrm{dbh}>5 \mathrm{~cm})$ after leveling off the bark with a rasp. In order to have a balanced design the dendrometers were split half and half between the high density plot (HDP) and the low density plot (LDP). We selected a balanced representation of the whole range of tree diameters observed in the study area for each tree species. We monitored the secondary growth of $21 P$. pinea trees (12 in the HDP and 9 in the LDP), 13 Q. ilex trees (5 in the HDP and 8 in the LDP) and 24 J. thurifera trees (12 in the HDP and 12 in the LDP). The dendrometer bands were revisited on 59 occasions on a regular basis (average period $17 \pm 6$ days) from May 2012 to April 2015 and the girth of each tree was measured with a precision of $0.1 \mathrm{~mm}$. To avoid diurnal biases due to changes in tree water status (Baker et al. 2002), all measurements were taken at around $11 \mathrm{am}$. Details on the characteristics of the selected trees are listed in Table 2.

Daily climatic variables including mean, maximum and minimum temperatures, daily precipitation, days without precipitation and days with frost were gathered from a meteorological station located in the area of study $\left(41^{\circ} 34^{\prime} \mathrm{N}, 4^{\circ} 20^{\prime} \mathrm{W}, 2.5 \mathrm{~km}\right.$ from the study site) and managed by the local forest service. $5.9 \%$ of absent data were estimated using data from Valbuena de Duero meteorological station $\left(41^{\circ} 38^{\prime} \mathrm{N}, 4^{\circ} 17^{\prime} \mathrm{W}, 6 \mathrm{~km}\right.$ from the study site), which are available from www.inforiego.org. 


\subsection{Data analysis and statistical methods}

\subsubsection{Modelling approach}

149 Due to the hierarchical structure of the data, three indices were defined, $i, j$ and $s$, which represent the tree, the time interval between measurements and the species, respectively. We chose the girth increment $(\mathrm{mm})$ as the response variable $\left(\mathrm{gi}_{\mathrm{ijs}}\right)$. It was defined as the difference between the girth observations in two consecutive measurements. Since our objective was to study the effects involved in wood expansion at breast height, we smoothed our original dendrometer series (Delpierre et al. 2016) by specifying that no shrinkage in girth increment was allowed, thus negative values for gi $i_{\mathrm{ijs}}$ were set to zero. A logarithmic transformation was applied to comply with the assumption of normality and homogeneous variances:

157

$y_{i j s}=\log \left[\left(g i_{i j s} \cdot 10\right)+1\right]$

158

159

160

161

162

163

164

We assumed there were some daily potential effects acting at tree level that define a theoretical daily maximum secondary growth and climate covariates that limit this potential growth. The daily potential effects $\left(\mathrm{PE}_{\mathrm{is}}\right)$ represent the expected growth when the other factors are at optimal values. Thus, the sum of the daily effects over the time interval $j$ can be used to predict the total secondary growth during this interval.

Among the $\mathrm{PE}_{\mathrm{is}}$, we included tree-level covariates: inter- and intraspecific competition indices $\left(\mathrm{AOI}_{\text {inter,is }}, \mathrm{AOI}_{\text {intra,is }}\right), \mathrm{dbh}_{\mathrm{i}}$ and a species effect (see eq. 2). We used the area overlap distance dependent competition indices (AOI) developed by Bella (1971) and later modified by Tomé and Burhart (1989) to define inter- and intraspecific interactions between the trees of the area of study. Further details on the description and use of these indices are annexed to this paper (See Appendix).

Given the hierarchical structure of the data, it could be suspected that there would be a violation of the assumption of independence. In order to account for this assumption, a tree random effect $\left(\mathrm{u}_{\mathrm{i}}\right)$ was included on the intercept. We assumed that the differences in stand density among both two plots were accounted for by the inter- and intraspecific competition indices. Additionally, since both plots were 
172 adjacent, we did not consider the inclusion of a random plot effect accounting for unobservable effects

173 due to differences in site conditions.

$174 P E_{i s}=\alpha_{s}+\left(\beta_{s} \cdot A O I_{\text {inter }, \text { is }}\right)+\left(\gamma_{s} \cdot A O I_{\text {intra }, i s}\right)+\left(\theta_{s} \cdot d b h_{i}\right)+u_{i}$

175

176

177

178

179

180

181

182

183

184

185

186

187

188

189

190

191

192

193

194

195

$196 T E_{m s}=\exp \left[-\frac{\left(T_{m}-\mu_{s}\right)^{2}}{\sigma_{s}^{2}}\right]$

where $m$ extends from the first day to the last day of the increment period $j, \mathrm{PE}_{\text {is }}$ represents the potential effects as defined in eq. 2 and $\mathrm{TE}_{\mathrm{ms}}, \mathrm{FE}_{\mathrm{ms}}$ and $\mathrm{DE}_{\mathrm{ms}}$ represent the temperature, frost and drought effects at the day $m$ on species $s$, respectively. These three effects were expressed as nonlinear functions of climatic variables.

The functions were designed to range from 0 (total inhibition of potential growth) to 1 (growth reaches all its potential). Stem growth response to temperature can adopt different shapes depending on the species and can even vary between subspecies of the same genus (Lempereur et al. 2015, Mayoral et al. 2015). We chose a Gaussian function for the temperature effect since it had been found adequate in other modelling approaches for $Q$. ilex subsp. ballota and $P$. pinea in mixed and monospecific $P$. pinea forests in the Iberian peninsula (Manso et al. 2013, Mayoral et al. 2015) under similar climatic conditions as in our study site. The function can be expressed as follows: 
197

198

199

200

201

202

203

204

205

206

207

208

209

210

211

212

213

214

215

216

217

218

219

220

221

222

where $T_{m}$ is either daily average temperature $\left(T_{a v, m}\right)$ or daily maximum temperature $\left(T_{\max , m}\right), \mu_{s}$ stands for optimum daily average temperature $\left(\mu_{\mathrm{av}, \mathrm{s}}\right)$ or optimum daily maximum temperature $\left(\mu_{\mathrm{max}, \mathrm{s}}\right)$ for species $s, \sigma_{\mathrm{s}}^{2}$ represents the variance of the normally distributed response of secondary growth to $\mathrm{T}_{\mathrm{m}}$ for species $s$.

In the case of frost and drought, we assumed they would have a long lasting effect on secondary growth. Freezing was thought to inhibit girth increment as a function of the number of days since the last frost, with the maximum growth reduction on the very day the frost event occurred. Hence, it was parametrised as:

$F E_{m s}=1-\exp \left(\varphi_{s} \cdot D F\right)$

where $\varphi_{\mathrm{s}}$ is the parameter associated to the frost effect on species $s$, which was expected to adopt negative values; DF stands for days since the last frost.

In regard of drought effects, two approaches were tested (eq. 6.1 and eq. 6.2.1):

$D E_{m s} 1=\exp \left(\lambda_{s} \cdot D P\right)$

$D E_{m s} 2=1-\exp \left(\delta_{s} \cdot W R_{m}\right)$

$W R_{m}=\left(P_{m}+W R_{m-1}\right) \exp (\lambda \cdot D P)$

where $\mathrm{DE}_{\mathrm{ms}}$ is the drought effect on species $s$ on day $m$, DP are the days since the last precipitation event. For the second approach, $\mathrm{WR}_{\mathrm{m}}$ is a proxy for the daily water reserve on day $m$, and is iteratively computed considering precipitation on day $m, \mathrm{P}_{\mathrm{m}}$, the value of $\mathrm{WR}_{\mathrm{m}}$ in the previous day $m-1$, and DP. $\lambda_{\mathrm{s}}$ and $\delta_{\mathrm{s}}$ are two specific parameters approaching how soil water content diminishes as days without precipitation increase, thus they should adopt negative values.

The combination of the climatic effects and the daily potential, as shown in eq. 3 , yields the cumulative effects $\mathrm{CE}_{\mathrm{ijs}}$ that we tried to use as a predictor of $g i_{i j s}$. After preliminary checks of the residuals, we found out that a log-transformation of $\mathrm{CE}_{\mathrm{ijs}}$ was needed, the resulting model being as follows:

$\log \left[\left(g i_{i j s} \cdot 10\right)+1\right]=\log \left(C E_{i j s}+1\right)+\epsilon_{i j s}$

where $\varepsilon_{\mathrm{ijs}}$ is the error term such that $\varepsilon_{\mathrm{ijs}} \sim \mathrm{N}\left(0, \sigma^{2}\right)$, with $\sigma^{2}$ the residual variance. 


\subsubsection{Model fitting}

224

225

226

227

228

229

230

231

232

233

234

235

236

237

238

239

240

241

242

243

244

245

246

247

248

249

250

The model was fitted using a maximum likelihood estimator. We followed a sequential procedure to select the effects entering the model: (i) competition and size factors determining daily potential growth, (ii) thermal effects, (iii) drought related effects, (iv) random effects, (v) species specific climatic responses. Preliminary models attained at each step of the model construction were compared in terms of bias (standardized residuals plotted against time), level of significance of the parameter estimates included and three different criteria for model comparison (Akaike information criterion, Bayesian information criterion and minus twice the maximum log-likelihood). At each step, the residuals were checked to identify heteroscedastic patterns. All calculations were carried out using PROC NLMIXED in SAS 9.2. (SAS Institute Inc. 2009).

\subsubsection{Model evaluation}

The model evaluation was primarily carried out by computing goodness-of-fit statistics such as mean error (E), root mean square error (RMSE) and modelling efficiency (MEF), computed over the residuals in real scale. The model was evaluated at different scales: whole data-set, per species, per plot and per combination of species and plot. A second evaluation was based on visual comparison of the girth increment trajectories between observed and predicted values. Finally, the accuracy of the model in predicting cumulative girth increment at tree level for the whole period was also tested at different scales by means of E, RMSE and MEF. We performed a t-test on the mean error under the null hypothesis that the model was correct, i.e. E was equal to 0. Consequently, any significant probability could be interpreted as a lack of fit. Evaluation of the model was carried out over raw, nontransformed values, thus antilogarithmic back-transformation of predicted values was carried out by multiplying the exponential of the predicted value per 0.5 times the variance of the error terms (Duan 1983).

\subsubsection{Model validation}

We did a model validation over a set of trees from the two plots included in the assay. The growth increment data used for the validation was obtained from cores and cross section slices extracted in 2011, thereby corresponding to different years than the ones considered to study girth increment (2012-2015). These cores and cross section slices were obtained from a representative sample of trees 
251

252

253

254

255

256

257

258

259

260

261

262

263

264

265

266

covering the whole range of diameters identified in the area of study. Total number of trees used in the validation were 48 P. pinea (24 per plot), $15 \mathrm{~J}$. thurifera ( 7 from the low density plot, 8 from the high density plot) and 4 Q. ilex (2 per plot). Q. ilex trees used for the validation had to be felled, which explains the lower amount of $Q$. ilex trees used for the validation compared to the other species. Model validation was based on computing the Pearson's correlation coefficient between the observed values of the annual radial increment (taken from increment cores and cross section slices) and the predicted annual girth increment obtained from our model. Temporal extent of the validation covered from 1997 to 2011 (15 years). Correlation coefficients were thus computed using the 15 observed-predicted annual values for each tree. We did not convert annual girth increment data into annual radial increment since girth measurements take into account bark growth but core increments do not.

\subsubsection{Growth projections under current and forecasted climate scenarios}

The final model was used to predict annual girth increment for the three species comparing current climate data with simulated climate data from IPCC RCP 8.5 climate scenario for 2075. Daily climate data were obtained from AEMET projections using climate model ACCESS 1-0 (http://www.aemet.es/es/serviciosclimaticos/cambio_climat/datos_diarios), resulting in a $4.5-^{\circ} \mathrm{C}$ increase of the average temperature, and a $30 \%$ decrease in annual rainfall. For this simulation competition was not considered.

\section{Results}

\subsection{Definition of secondary growth function}

The sequential process of construction of the models for the secondary growth is shown in Table 3 . At each step of the model construction a new factor was included and compared in terms of -2LL, AIC and BIC with the same model without this effect. Among the main constant factors determining the daily potential growth tree dbh was discarded as it was only significant for $J$. thurifera and it did not improve the performance of the model either (models [1] and [2]). Hence, daily potential girth increment was defined by a species effect in the intercept and inter- and intraspecific competition indices. With respect to thermal effects, mean daily temperature resulted in a best fit than maximum temperature (models [3] and [4]). Integrating the frost effect did not improve the model significantly, 
consequently the frost effect was removed in the process of model construction (models [4] and [5]). However both drought approaches tested were significant. Drought effect 2 was chosen in preference to drought effect 1 since it improved the model fit in terms of AIC, BIC and -2LL when compared with the same model with drought effect 1 (models [6]-[7]). The inclusion of a tree random effect resulted in a significant improvement in terms of AIC, BIC and -2LL (models [7] and [8]). We finally tested the different alternatives of inclusion of specific interactions on the climatic effects (models [9][15]). The fit of the complete model [15] could not be attained due to convergence problems. Comparison among models [9]-[14] resulted in very minor differences. We finally opted to select the model [12], including specific parameters for thermal amplitude and drought effect and a common parameter for drought occurrence, as it can be considered a good compromise between goodness of fit and parsimony in the number of parameters entering the model. Table 4 presents the parameter estimates of the preferred model.

\subsection{Factors affecting intraannual growth patterns}

The final girth increment model produced a hyperplane, depending on biotic and abiotic interactions from which we could infer contrasting growth responses by species for the different factors. Growth patterns were characterized by a succession of sharp increases followed by plateaus, which corresponded to growth increments during spring and fall periods and growth cessation in summer and winter times, respectively (Fig. 1).

\subsubsection{Daily potential effects}

The species effect on the intercept $\left(\alpha_{\mathrm{s}}\right)$ was significant for the three species implying different average girth increments for each of them. The effect was greater for P. pinea $\left(\hat{\alpha}_{1}=3.5498\right)$, followed by $Q$. ilex $\left(\hat{\alpha}_{2}=2.0815\right)$ and $J$. thurifera $\left(\hat{\alpha}_{3}=1.9852\right)$. Concerning interspecific competition, significant values were observed for $Q$. ilex $(\mathrm{P}$-value $=0.034)$ and close to significant for $J$. thurifera $(\mathrm{P}$-value $=$ 0.055), being growth inhibition larger for $Q$. ilex $\left(\widehat{\beta}_{2}=-0.09597\right)$ than for $J$. thurifera $\left(\widehat{\beta}_{3}=-0.05453\right)$. Interspecific competition effect was not significant for $P$. pinea $(\mathrm{P}$-value $=0.527)$. With respect to intraspecific competition we obtained a significant inhibition of the potential girth increment for $P$. pinea $(\mathrm{P}$-value $=<0.001)$ and $J$. thurifera $(\mathrm{P}$-value $=0.010)$, being more than two times lower for $P$. 
pinea $\left(\hat{\gamma}_{1}=-0.1692\right)$ than for $J$. thurifera $\left(\hat{\gamma}_{3}=-0.3425\right)$. The effect of intraspecific competition was

307

308

309

310

311

312

313

314

non-significant for $Q$. ilex $(\mathrm{P}$-value $=0.409)$.

\subsubsection{Climate covariates}

As regards the temperature effect, optimum daily average temperatures for secondary growth were $16.4{ }^{\circ} \mathrm{C}$ for $P$. pinea $\left(\hat{\mu}_{1}\right), 32.0^{\circ} \mathrm{C}$ for $Q$. ilex $\left(\hat{\mu}_{2}\right)$ and $17.8{ }^{\circ} \mathrm{C}$ for $J$. thurifera $\left(\hat{\mu}_{3}\right)$. The scaled normally distributed response of girth increment to daily average temperature differed between species, being three times greater for $Q$. ilex $\left(\widehat{\sigma}_{2}^{2}=210.3400\right)$ than for $J$. thurifera $\left(\hat{\sigma}_{3}^{2}=67.4487\right)$ and P. pinea $\left(\hat{\sigma}_{1}^{2}=64.7046\right)$ pointing to a wider thermal amplitude for $Q$. ilex than for the other tree species. The symmetric thermal intervals, together with the optimum average temperatures and different thermal amplitudes by species, can be seen in Fig. 2a. With respect to the drought effect on girth increment, it differed across the species, being more limiting for the intraannual secondary growth of $P$. pinea $\left(\widehat{\delta}_{1}=-0.1382\right)$ and $J$. thurifera $\left(\widehat{\delta}_{3}=-0.1123\right)$ than for $Q$. ilex $\left(\widehat{\delta}_{2}=-0.2559\right)$. To facilitate the interpretation of the drought effect, we ran a simulation considering initial water reserve values of 0 and a single episode of precipitation of $5 \mathrm{~mm}$ on the first day of the simulation (Fig. 2b). Lower values obtained for the drought effect for P. pinea $(0.4989)$ and $J$. thurifera $(0.4297)$ than for Q. ilex (0.7218), the first day of the simulation imply that $Q$. ilex makes better use of water than the other two species after an isolated rainfall event when soil water reserves are scarce.

\subsection{Model evaluation}

Accuracy of the model was first evaluated by means of common statistics as mean error, root mean square error and modelling efficiency, for the whole data set, and separately for each plot, species and each combination of plot and species (Table 5). Non-significant P-values under the null hypothesis that the mean error $(\mathrm{E})=0$ imply that the difference between observed and predicted values is nonsignificant and thereby there is no systematic bias in the predictions. Model predictions of girth increment were unbiased for all levels of grouping. At global scale, RMSE reached $0.694 \mathrm{~mm}$, with MEF over 33.4\%. We obtained more accurate predictions for the HDP than for the LDP, especially for $Q$. ilex, and $J$. thurifera. The main part of the observed bias was associated with $P$. pinea girth 
332

333

334

335

336

337

increment in the LDP. This result is mainly due to the unexpected larger summer growth in 2014 observed in three pines in the LDP.

The visual agreement between average observed and predicted increment trajectories through the whole cycle (Fig. 1), perfectly mimicking the bimodal growth patterns, again points to a better performance of the model in the HDP than in the LDP, particularly for predicting the secondary growth of Q. ilex and J. thurifera.

We finally tested the ability of the model to predict the cumulative girth increment of the 58 trees evaluated along the whole period of study (1 062 days). Unbiased predictions were obtained for all scales evaluated (Table 6, Fig. 3). The combinations of plot and species could not be tested due to the small number of trees involved in some combinations. The accuracy of the model was greater in predicting the girth increment in the HDP, than in the LDP, especially for J. thurifera. Once more, higher RMSE values for $P$. pinea are due to the unexpected summer growth of three dominant trees (Fig. 3). However, MEF reached values over $86 \%$ and RMSE below $5.6 \mathrm{~mm}$ for all the scales studied, showing a high agreement between observed and predicted values, and a notable long-term model accuracy.

\subsection{Model validation}

Model validation showed a clear agreement between observed annual increment data obtained from cores and cross section slices and the values of annual girth increment predicted using the model (Table 7). The main part of the tree-level correlations (63 out of 67 ) between observed radial increment and predicted girth increment were positive and statistically significant. Average correlation values ranged from $0.40-0.55$ for all the species and plots, with maximum values of $0.57-0.75$ depending on the species. Models for $P$. pinea and $Q$. ilex performed better in the high-density plot, while models for $J$. thurifera performed better in the low-density plot.

The model mimicked the pattern of interannual variability in radial increment (Fig. 4), especially in the last years of the simulation (2005-2011). However, the model was not able to match perfectly the effect of the 2002 thinning carried out in the low density plot, since we predicted a 2-year delayed response with respect to the real observed values (Fig. 4a, 4b and 4c).

3.5. Growth projections under changing climate scenarios 
360

361

362

363

364

365

366

367

368

369

370

371

372

373

374

375

376

377

378

379

380

381

382

383

384

385

386

387

The results from our simulations under current climate and RCP 8.5. climate scenario indicate secondary growth reductions of $19.1 \%$ for $P$. pinea and $6.5 \%$ for $J$. thurifera and a growth increase of $61.6 \%$ for Quercus ilex under these simulated climate projections (Fig. 5). We would like to stress that competition was not considered for this simulation as the definitive model [12] only had slightly lower values in terms of minus twice the maximum log-likelihood $(-2 \mathrm{LL}=8650)$ when compared with the same model without competition $(-2 \mathrm{LL}=8689)$. Including competition at tree level also implied solving many technical problems when running the simulations. Thereby these growth projections are referred to open grown trees and must be treated with caution.

\section{Discussion}

4.1. Advantages from a multifactorial non-linear approach for intraannual tree growth $\underline{\text { studies }}$

Linear correlations between growth estimates and different climatic variables (Camarero et al. 2010, Michelot et al. 2012) and linear mixed models (e.g. Martín et al., 2015) have been used to study intraannual growth dynamics. However many climate-growth interactions are known to be non-linear. Previous studies have also highlighted the need of integrating both competition and climatic data for intraannual tree growth studies (Gutiérrez et al. 2011). In the Mediterranean areas many climatic factors like high temperatures, elevated transpiration and soil water depletion intervene simultaneously constraining intraannual girth increment. We thereby propose a non-linear multifactorial approach that can cope with all this limitations allowing us to understand the ecological needs of different species at one time.

\subsection{Intraannual growth patterns}

Many studies have found different growth dynamics in pine and oak species during the growing season concerning the date of budburst, leaf unfolding, radial growth onset and cessation, secondary growth rates or contrasting patterns of carbon allocation (e.g. Michelot et al., 2012; Zweifel et al., 2006). Girth increment data obtained from band dendrometers have limitations to identify some phenological events due to the reversible stem shrinking and swelling. However, we believe our model 
represents a good alternative to study girth increment based on daily and cumulative climatic effects as it only considers stem growth with stem shrinkage set to values of zero. Model predictions for cumulative girth increment were unbiased and show a notable long-term model accuracy. The general growth rates of the three tree species we studied (Ruiz de la Torre 2006) indicate that $P$. pinea has the highest potential girth increments followed by $J$. thurifera and $Q$. ilex which is consistent with the intercept values we obtained. Previous studies in the Iberian peninsula (Campelo et al. 2007b, Camarero et al. 2010, Martín et al. 2014) have reported bimodal growth patterns for the three species over the year, characterized by a succession of sharp growth increases followed by plateaus, which is in line with our results. Diameter growth increased mainly during spring and autumn, coinciding periods of higher precipitation, increased soil water reserves and milder temperatures for growth (Pinto et al. 2011). Girth increment was repressed in summer, which is in agreement with a growth inhibition by high average temperatures and soil water deficit during the summer (Campelo et al. 2009). Secondary growth also stopped in winter, probably due to cambial dormancy caused by low average temperatures (Liphschitz et al. 1984, Gea-Izquierdo et al. 2009) and photoperiod shortening (Cherubini et al. 2003).

\subsection{Size effects and intraannual competition differences between and within species}

We obtained significant growth restrains by interspecific competition for $J$. thurifera and $Q$. ilex. Interspecific competition was also size-symmetric (De-Dios-García et al. 2015), implying that resource uptake is independent of target tree sizes and takes place mainly for belowground resources (Schwinning and Weiner 1998). However interspecific competition was not significant for P. pinea on a daily basis. Juniper trees seem to develop shallower root systems in drought stressed sites than cooccurring pine species (Willson et al. 2008) while Mediterranean oaks tend to develop large taproots reaching deeper soil layers when growing in drought-prone environments (Canadell et al. 1996). We further obtained competitive reduction for $J$. thurifera, interspecific interactions being less intense than intraspecific interactions, which is another proof of niche partitioning and interspecific differentiation in resource use (Forrester 2014).

Intraspecific competition was significant for $J$. thurifera and $P$. pinea having in both cases a negative impact on secondary growth. Intraspecific interactions, as defined by the competition index (De-Dios- 
García et al. 2015), were also size-asymmetric, indicating that larger trees benefit from a larger part of

417 the resources, which limits the growth of their smaller conspecific neighbours (Schwinning and

Weiner 1998). However and contrary to our third hypothesis, the effect of intraspecific competition on girth increment was two fold in $J$. thurifera compared to $P$. pinea. Low levels of intraspecific competition imply complete growth cessation for $J$. thurifera, but not for $P$. pinea. The more limiting effect of intraspecific competition on $J$. thurifera secondary growth could be due to their clumped spatial pattern (unpublished data) found in the field around bigger $P$. pinea trees. In the case of the evergreen oak $Q$. ilex intraspecific competition indices were not significant. A large scale study on the 15 most important tree species in the Iberian peninsula indicated that Mediterranean evergreen broadleaved species were the least sensitive to competition in terms of growth (Gómez-Aparicio et al. 2011). Another explanation for this result might be the low diameters found for $Q$. ilex in these forests that were intensively coppiced for fuelwood and charcoal production until 1950s, constituting nowadays mainly a coppice forest.

\subsection{Secondary growth responses to climate are species dependent}

Previous studies state that the main climatic effects constraining intrannual secondary growth of $Q$. ilex are temperature at short time scales (Gutiérrez et al. 2011) and water availability (Corcuera et al. 2004, Martín et al. 2014), which were both significant in our study. $J$. thurifera is also known to have a pronounced phenological activity, with a strong cambium dormancy in xeric sites during summer and a radial growth resumption due to cambium reactivation following late-summer and autumn rainfalls (Camarero et al. 2010). We obtained higher autumn girth increments for $J$. thurifera than for Q. ilex. Autumn precipitation events are known to moisten only the most superficial soil layers in Mediterranean continental areas (Camarero et al. 2010). Since $J$. thurifera roots are mainly developed in the upper soil profile, this may provide them a competitive advantage, allowing them to invest more resources on diameter growth than co-occurring pines and oaks during the autumn season. As regards P. pinea, latewood formation, which occurs during the summer, is limited by drought stress and 441 extreme temperatures (Campelo et al. 2007b).

442 Recent studies on mixed $P$. pinea stands in the Spanish central range have identified higher optimum temperatures for photosynthesis for Q. ilex than for P. pinea and other Juniper species (Mayoral et al. 
2015), which are consistent with the optimum temperatures for growth that we obtained for each of these species. These results are also in accordance with a more thermophilic and light demanding strategy for $Q$. ilex than for P. pinea and J. thurifera trees. However, studies on intraannual growth in other Pinus and Quercus species indicate that the carbon fixed through photosynthesis is not directly used for radial growth in above-ground wood, evidencing that the early phase of radial growth completely depends on internal C-stores (Zweifel et al. 2006).

The wider thermal amplitude obtained for $Q$. ilex, compared with $J$. thurifera and P. pinea confirms the eurythermic character of this species, as it had been previously outlined in the literature (Ruiz de la Torre 2006), capable of maintaining secondary growth along a wide thermal range. Gea-Izquierdo et al. (2009) found a negative correlation between high temperatures and growth for $Q$. ilex. Our results indicate that considering only elevated temperatures is not sufficient to explain this growth suppression. A combined effect of high temperatures, elevated evapotranspiration and soil water stress could cause the secondary growth inhibition, as observed in this study.

Drought effect was significant and inhibited growth for all species. However it was less limiting for $Q$. ilex than for $J$. thurifera and P. pinea. Other studies have found different growth responses to drought events between pine and oak species, oaks being more resistant to summer droughts and pine species being more resistant to spring droughts (e.g. Morán-López et al., 2014). Pine trees are known to unfold their needles during the summer and can attain one fourth of the total annual radial growth by the time their leaves reach full expansion (Zweifel et al. 2006). However summer droughts, which were the main drought events that occurred during the period of study, can strongly affect the secondary growth of pines since they hamper needle formation and cell enlargement reducing their radial increment (Merlin et al. 2015). Furthermore, both Q. ilex and J. thurifera are known to profit from isolated summer rainfalls (Corcuera et al. 2004, Camarero et al. 2010, Gutiérrez et al. 2011) activating xylogenesis and expanding their radial growth forming double rings (Campelo et al. 2007a). As opposed to this, $P$. pinea cannot benefit from this water supply during the driest months of the year (Campelo et al. 2007b). This behaviour in Q. ilex is particularly interesting in trees living in a Mediterranean continental area. Diameter growth during the summer has been observed in $Q$. ilex trees living in more mesic locations (Cherubini et al. 2003). However, studies from open Q. ilex woodlands 
472 in continental sites in the Iberian peninsula, with similar precipitation regimes and lower stand

473 densities obtain opposite growth tendencies with respect to late-summer precipitations (Gea-Izquierdo 474 et al. 2009). We hypothesize that similar precipitation regimes in Mediterranean continental sites may 475 be more favourable in mixed forests, due to niche complementarity, leading to less water-stressed conditions in the summer for evergreen broadleaf trees.

\subsection{Model validation and growth projections}

There is a marked recent tendency towards drier and hotter summer seasons in the region of study according to historical data (1975-2010) from Valladolid meteorological station (www.aemet.com). The model was constructed with data from 2012-2015, therefore considering more similar climate conditions to the ones found in the last period of the validation (2005-2011). The low density plot was also subjected to thinning practices to reduce stand density in 2002. The effect of thinning on the secondary growth of remaining trees was not considered in the model, which was constructed with girth increment data from 2012-2015, ten years after the thinning treatment was applied. We believe this may explain the poorer model performance in the first years of the validation and the more accurate growth predictions three years after the thinning treatments were applied.

According to our model projections for 2075 the $4.5^{\circ} \mathrm{C}$ increase on average temperature and $30 \%$ decrease in annual rainfall expected in the region of study will negatively affect the secondary growth of $P$. pinea. If competition were included in these projections, intraspecific competition may even be translated in lower secondary growths for $P$. pinea. Q. ilex will be favoured maybe due to its wider thermal amplitude; however reduced growth could be expected if interspecific competition were considered. J. thurifera will remain practically unaffected but may have slight growth reductions including inter- and intraspecific competition.

\subsection{Conclusions}

Forest managers should be cautious to extrapolate these results at a forest management scale due to the low explained growth variance, particularly for $P$. pinea growing in mixed stands in low densities. However our predictions for cumulative girth increment show a notable long-term model accuracy. We thereby believe that this model is a useful tool to describe the effect of inter- and intraspecific competition and different climate change scenarios on secondary growth and may help orientate forest 
500 management decisions. Current management practices in the Spanish Northern Plateau have favoured $501 P$. pinea over $Q$. ilex. Based on all the previous findings and in accordance with the simulations 502 carried out with the model for future climate scenarios, forest managers may wish to modify their 503 management schedules lowering $P$. pinea stand densities and promoting species like $Q$. ilex in 504 mixtures, with a higher plasticity in response to climatic conditions during the growing season 505 (Gutiérrez et al. 2011). In line with other authors (Gea-Izquierdo et al. 2009), we believe this would be 506 a more balanced stand combination in sclerophyllous oak-conifer mixtures, better adapted to the 507 expected change in climatic conditions. 


\section{Acknowledgements}

510 We are grateful to the Forest Service of Castilla y León administration for permission and support to 511 carry out the field experiment. We also wish to thank Mar Conde, Enrique Garriga and Guillermo

512 Madrigal for their help in the data collection. This work was supported by the Spanish Ministry of 513 Economy and Competitiveness (MINECO) [grant FPI BES-2011-050760 to J.D.G., projects AGL514 2010-15521 and RTA-2013-00011-C02-01]; by the National Institute for Agricultural and Food 515 Research and Technology from Spain (INIA) [AT-2013-004]; and by the agreement between 516 ITACyL-Diputación de Valladolid-INIA [CC-16-095-PROPINEA]. The UMR 1092 LERFoB is

517 supported by a grant overseen by the French National Research Agency (ANR) as part of the 518 "Investissements d'Avenir programme" [ANR-11-LABX-0002-01, Lab of Excellence ARBRE]. 


\section{References}

Baker, T.R., Affum-Baffoe, K., Burslem, D.F.R.P., and Swaine, M.D. 2002. Phenological differences in tree water use and the timing of tropical forest inventories: Conclusions from patterns of dry season diameter change. For. Ecol. Manage. 171(3): 261-274. doi:10.1016/S03781127(01)00787-3.

Bella, I.E. 1971. A new competition model for individual trees. For. Sci. 17(3): 364-372. Available from http://www.ingentaconnect.com/content/saf/fs/1971/00000017/00000003/art00022.

Camarero, J.J., Olano, J.M., and Parras, A. 2010. Plastic bimodal xylogenesis in conifers from continental Mediterranean climates. New Phytol. 185(2): 471-480. doi:10.1111/j.14698137.2009.03073.x.

Campelo, F., Gutiérrez, E., Ribas, M., Nabais, C., and Freitas, H. 2007a. Relationships between climate and double rings in Quercus ilex from northeast Spain. Can. J. For. Res. 37(10): 19151923. doi:10.1139/X07-050.

Campelo, F., Nabais, C., Freitas, H., and Gutiérrez, E. 2007b. Climatic significance of tree-ring width and intra-annual density fluctuations in Pinus pinea from a dry Mediterranean area in Portugal. Ann. For. Sci. 64(2): 229-238. doi:10.1051/forest.

Campelo, F., Nabais, C., García-González, I., Cherubini, P., Gutiérrez, E., and Freitas, H. 2009. Dendrochronology of Quercus ilex L. and its potential use for climate reconstruction in the Mediterranean region. Can. J. For. Res. 39(12): 2486-2493. doi:10.1139/X09-163.

Canadell, J., Jackson, R.B., Ehleringer, J.B., Mooney, H.A., Sala, O.E., and Schulze, E.D. 1996. Maximum rooting depth of vegetation types at the global scale. Oecologia 108(4): 583-595. doi:10.1007/BF00329030.

Cherubini, P., Gartner, B.L., Tognetti, R., Bräker, O.U., Schoch, W., and Innes, J.L. 2003. Identification, measurement and interpretation of tree rings in woody species from Mediterranean climates. Biol. Rev. Camb. Philos. Soc. 78(1): 119-148. doi:10.1017/S1464793102006000. 
Cleland, E.E., Chuine, I., Menzel, A., Mooney, H.A., and Schwartz, M.D. 2007. Shifting plant phenology in response to global change. Trends Ecol. Evol. 22(7): 357-365. doi:10.1016/j.tree.2007.04.003.

Corcuera, L., Camarero, J.J., and Gil-Pelegrín, E. 2004. Effects of a severe drought on Quercus ilex radial growth and xylem anatomy. Trees - Struct. Funct. 18(1): 83-92. doi:10.1007/s00468-0030284-9.

De-Dios-García, J., Pardos, M., and Calama, R. 2015. Interannual variability in competitive effects in mixed and monospecific forests of Mediterranean stone pine. For. Ecol. Manage. 358: 230-239. doi:10.1016/j.foreco.2015.09.014.

Delpierre, N., Berveiller, D., Granda, E., and Dufrêne, E. 2016. Wood phenology, not carbon input, controls the interannual variability of wood growth in a temperate oak forest. New Phytol. 210(2): 459-470. doi:10.1111/nph.13771.

Duan, N. 1983. Smearing estimate: a nonparametric retransformation method. J. Am. Stat. Assoc. 78(383): 605-610. doi:10.1080/01621459.1983.10478017.

Forrester, D.I. 2014. The spatial and temporal dynamics of species interactions in mixed-species forests: From pattern to process. For. Ecol. Manage. 312(2014): 282-292. Elsevier B.V. doi:10.1016/j.foreco.2013.10.003.

Gea-Izquierdo, G., Martín-Benito, D., Cherubini, P., and Cañellas, I. 2009. Climate-growth variability in Quercus ilex L. west Iberian open woodlands of different stand density. Ann. For. Sci. 66(8): 802p1-802p12. doi:10.1051/forest/2009080.

Gómez-Aparicio, L., García-Valdés, R., Ruíz-Benito, P., and Zavala, M.Á. 2011. Disentangling the relative importance of climate, size and competition on tree growth in Iberian forests: implications for forest management under global change. Glob. Chang. Biol. 17(7): 2400-2414. doi:10.1111/j.1365-2486.2011.02421.x.

Grogan, J., and Schulze, M. 2012. The impact of annual and seasonal rainfall patterns on growth and 
phenology of emergent tree species in Southeastern Amazonia, Brazil. Biotropica 44(3): 331340. doi:10.1111/j.1744-7429.2011.00825.x.

Grossiord, C., Granier, a., Ratcliffe, S., Bouriaud, O., Bruelheide, H., Checko, E., Forrester, D.I., Dawud, S.M., Finer, L., Pollastrini, M., Scherer-Lorenzen, M., Valladares, F., Bonal, D., and Gessler, a. 2014. Tree diversity does not always improve resistance of forest ecosystems to drought. Proc. Natl. Acad. Sci. 111(41): 14812-14815. doi:10.1073/pnas.1411970111.

Gutiérrez, E., Campelo, F., Camarero, J.J., Ribas, M., Muntan, E., Nabais, C., and Freitas, H. 2011. Climate controls act at different scales on the seasonal pattern of Quercus ilex L. stem radial increments in NE Spain. Trees - Struct. Funct. 25(4): 637-646. doi:10.1007/s00468-011-0540-3.

Lebourgeois, F., Gomez, N., Pinto, P., and Mérian, P. 2013. Mixed stands reduce Abies alba tree-ring sensitivity to summer drought in the Vosges mountains, western Europe. For. Ecol. Manage. 303: 61-71. doi:10.1016/j.foreco.2013.04.003.

Lebourgeois, F., Rathgeber, C.B.K., and Ulrich, E. 2010. Sensitivity of French temperate coniferous forests to climate variability and extreme events (Abies alba, Picea abies and Pinus sylvestris). J. Veg. Sci. 21(2): 364-376. doi:10.1111/j.1654-1103.2009.01148.x.

Lempereur, M., Martin-Stpaul, N.K., Damesin, C., Joffre, R., Ourcival, J.M., Rocheteau, A., and Rambal, S. 2015. Growth duration is a better predictor of stem increment than carbon supply in a Mediterranean oak forest: Implications for assessing forest productivity under climate change. New Phytol. 207(3): 579-590. doi:10.1111/nph.13400.

Liphschitz, N., Lev-Yadun, S., Rosen, E., and Waisel, Y. 1984. The annual rythm of activity of the lateral meristems (cambium and phellogen) in Pinus halepensis Mill. and Pinus pinea L. IAWA Bull. 5(4): 263-274. doi:10.1017/CBO9781107415324.004.

Manso, R., Fortin, M., Calama, R., and Pardos, M. 2013. Modelling seed germination in forest tree species through survival analysis. The Pinus pinea L. case study. For. Ecol. Manage. 289: 515524. doi:10.1016/j.foreco.2012.10.028. 
Manso, R., Morneau, F., Ningre, F., and Fortin, M. 2015. Effect of climate and intra- and inter-specific competition on diameter increment in beech and oak stands. Forestry 88(5): 540-551. doi:10.1093/forestry/cpv020.

Martín, D., Vázquez-Piqué, J., Carevic, F.S., Fernández, M., and Alejano, R. 2015. Trade-off between stem growth and acorn production in holm oak. Trees - Struct. Funct. 29(3): 825-834. doi:10.1007/s00468-015-1162-y.

Martín, D., Vázquez-Piqué, J., Fernández, M., and Alejano, R. 2014. Effect of ecological factors on intra-annual stem girth increment of holm oak. Trees - Struct. Funct. 28(5): 1367-1381. doi:10.1007/s00468-014-1041-y.

Mayoral, C., Calama, R., Sánchez-González, M., and Pardos, M. 2015. Modelling the influence of light, water and temperature on photosynthesis in young trees of mixed Mediterranean forests. New For. 46(4): 485-506. doi:10.1007/s11056-015-9471-y.

McMahon, S.M., and Parker, G.G. 2015. A general model of intra-annual tree growth using dendrometer bands. Ecol. Evol. 5(2): 243-254. doi:10.1002/ece3.1117.

Merlin, M., Perot, T., Perret, S., Korboulewsky, N., and Vallet, P. 2015. Effects of stand composition and tree size on resistance and resilience to drought in sessile oak and Scots pine. For. Ecol. Manage. 339: 22-33. Elsevier B.V. doi:10.1016/j.foreco.2014.11.032.

Michelot, A., Simard, S., Rathgeber, C., Dufrêne, E., and Damesin, C. 2012. Comparing the intraannual wood formation of three European species (Fagus sylvatica, Quercus petraea and Pinus sylvestris) as related to leaf phenology and non-structural carbohydrate dynamics. Tree Physiol. 32(8): 1033-1045. doi:10.1093/treephys/tps052.

Morán-López, T., Poyatos, R., Llorens, P., and Sabaté, S. 2014. Effects of past growth trends and current water use strategies on Scots pine and pubescent oak drought sensitivity. Eur. J. For. Res. 133(2): 369-382. doi:10.1007/s10342-013-0768-0.

Natalini, F., Correia, A.C., Vázquez-Piqué, J., and Alejano, R. 2015. Tree rings reflect growth 
adjustments and enhanced synchrony among sites in Iberian stone pine (Pinus pinea L.) under climate change. Ann. For. Sci. 72(8): 1023-1033. doi:10.1007/s13595-015-0521-6.

Paine, C.E.T., Marthews, T.R., Vogt, D.R., Purves, D., Rees, M., Hector, A., and Turnbull, L.A. 2012. How to fit nonlinear plant growth models and calculate growth rates: An update for ecologists. Methods Ecol. Evol. 3(2): 245-256. doi:10.1111/j.2041-210X.2011.00155.x.

Pinto, C.A., Henriques, M.O., Figueiredo, J.P., David, J.S., Abreu, F.G., Pereira, J.S., Correia, I., and David, T.S. 2011. Phenology and growth dynamics in Mediterranean evergreen oaks: Effects of environmental conditions and water relations. For. Ecol. Manage. 262(3): 500-508. Elsevier B.V. doi:10.1016/j.foreco.2011.04.018.

Pretzsch, H., Schütze, G., and Uhl, E. 2013. Resistance of European tree species to drought stress in mixed versus pure forests: evidence of stress release by inter-specific facilitation. Plant Biol. 15(3): 483-495. doi:10.1111/j.1438-8677.2012.00670.x.

Río, M., Pretzsch, H., Alberdi, I., Bielak, K., Bravo, F., Brunner, A., Condés, S., Ducey, M.J., Fonseca, T., von Lüpke, N., Pach, M., Peric, S., Perot, T., Souidi, Z., Spathelf, P., Sterba, H., Tijardovic, M., Tomé, M., Vallet, P., and Bravo-Oviedo, A. 2016. Characterization of the structure, dynamics, and productivity of mixed-species stands: review and perspectives. Eur. J. For. Res. 135(1): 23-49. doi:10.1007/s10342-015-0927-6.

Rossi, S., Anfodillo, T., and Deslauriers, A. 2006. Assessment of cambial activity and xylogenesis by microsampling tree species: An example at the alpine timberline. IAWA J. 27(4): 383-394. doi:10.1163/22941932-90000161.

Ruiz de la Torre, J. 2006. Flora mayor. Organismo Autónomo de Parques Nacionales. Ministerio de medio ambiente rural y marino, Madrid.

SAS Institute Inc. 2009. SAS/STAT® 9.2 user's guide, 2nd. Edition. SAS Institue Inc, Cary NC.

Schwinning, S., and Weiner, J. 1998. Mechanisms determining the degree of size asymmetry in competition among plants. Oecologia 113: 447-455. doi:10.1007/s004420050397. 
Tomé, M., and Burkhart, H.E. 1989. Distance-dependent competition measures for predicting growth of individual trees. For. Sci. 35(3): 816-831. Available from http://www.ingentaconnect.com/content/saf/fs/1989/00000035/00000003/art00015.

Urban, J., Bednářová, E., Plichta, R., and Kučera, J. 2013. Linking phenological data to ecophysiology of European beech. Acta Hortic. 991: 293-299. doi:10.17660/ActaHortic.2013.991.36.

Willson, C.J., Manos, P.S., and Jackson, R.B. 2008. Hydraulic traits are influenced by phylogenetic history in the drought-resistant, invasive genus Juniperus (Cupressaceae). Am. J. Bot. 95(3): 299-314. doi:10.3732/ajb.95.3.299.

Zweifel, R., Zimmerman, L., Zeugin, F., and Newbery, D.M. 2006. Intra-annual radial growth and water relations of trees: implications towards a growth mechanism. J. Exp. Bot. 57(6): 14451459. doi:10.1093/jxb/erj125. 
Table 1. Stand attributes, estimated using trees with diameter at breast height $\geq 5 \mathrm{~cm}$. N: stand density; G: basal area; Dg: quadratic mean diameter; H: mean total height; LDP: low density plot; HDP: high density plot.

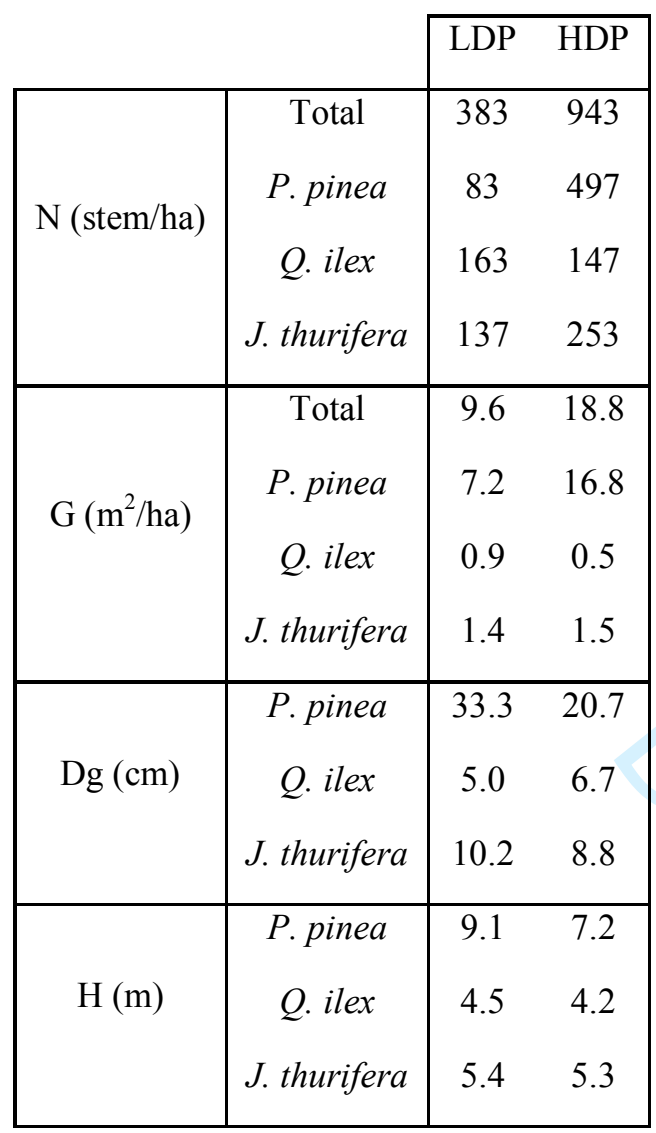


Table 2. Characteristics of the 58 trees with band dendrometers. Diameter classes correspond to: II $=5 \mathrm{~cm} \leq \mathrm{D}<10 \mathrm{~cm}, \mathrm{III}=10 \mathrm{~cm} \leq \mathrm{D}<15 \mathrm{~cm}, \mathrm{IV}=15 \mathrm{~cm} \leq \mathrm{D}<25 \mathrm{~cm}, \mathrm{~V}=25 \mathrm{~cm} \leq \mathrm{D}<35$.

\begin{tabular}{|llllll|}
\hline Species & Site & $\begin{array}{l}\text { Diameter } \\
\text { class }\end{array}$ & $\begin{array}{l}\text { Number of } \\
\text { trees }\end{array}$ & $\begin{array}{l}\text { Range of tree heights } \\
(\mathrm{m})\end{array}$ & $\begin{array}{l}\text { Range of dbh } \\
(\mathrm{cm})\end{array}$ \\
\hline Pinus pinea & $\begin{array}{l}\text { High } \\
\text { density }\end{array}$ & III & 4 & $6.2-7.1$ & $12.65-14.95$ \\
& & IV & 4 & $7.5-9.3$ & $23.2-24.8$ \\
& Low & III & 1 & $9.6-10.4$ & $25.5-34.35$ \\
& density & IV & 4 & $4.7-4.7$ & $12.25-12.25$ \\
& & V & 4 & $5.6-8.2$ & $18.05-24.25$ \\
Quercus ilex & High & II & 4 & $8.5-10.8$ & $28.45-34.3$ \\
& density & III & 1 & $3.7-5.4$ & $7.5-9.15$ \\
& Low & II & 5 & $6-6$ & $10.85-10.85$ \\
& density & III & 3 & $3.4-4.7$ & $5.6-9$ \\
\hline $\begin{array}{l}\text { Juniperus } \\
\text { thurifera }\end{array}$ & $\begin{array}{l}\text { High } \\
\text { density }\end{array}$ & II & 4 & $4.9-5.3$ & $10.05-10.9$ \\
& & III & 6 & $5.3-7.8$ & $8.8-9.65$ \\
& IV & 2 & $5.6-8.7$ & $11.1-14.85$ \\
& Low & II & 4 & $8.5-9$ & $17.7-20.6$ \\
& density & III & 4 & $3.7-6.1$ & $6.75-9.6$ \\
& & IV & 4 & $5.6-7.1$ & $11.35-14.35$ \\
& & & $7.2-8.8$ & $16.9-24.8$ \\
\hline
\end{tabular}


Table 3. Comparison of fitting statistics and sequential procedure for model construction. Intrasp.: Intraspecific; Intersp.: Interspecific; dbh ${ }_{\mathrm{i}}$ : diameter at breast height of the target tree $i ; \mathrm{T}_{\max }$ : daily maximum temperature; $\mathrm{T}_{\mathrm{av}}:$ daily average temperature; $\alpha_{\mathrm{s}}$ is the intercept for species $s ; \beta_{\mathrm{s}}:$ parameter associated to interspecific competition for species $s ; \gamma_{\mathrm{s}}$ : parameter associated to intraspecific competition for species $s ; \theta_{\mathrm{s}}$ : parameter associated to diameter at breast height of the target tree of species $s ; \mu_{s}$ : optimum daily temperature for species $s ; \lambda$ : parameter related to drought occurrence; $\lambda_{s}$ : parameter related to drought occurrence for species $s ; \delta$ : parameter linked to the drought effect; $\delta_{s}$ : parameter linked to the drought effect on species $s ; \sigma^{2}:$ variance of the scaled normally distributed response of secondary growth to daily temperature; $\sigma_{s}^{2}$ : variance of the scaled normally distributed response of secondary growth to daily

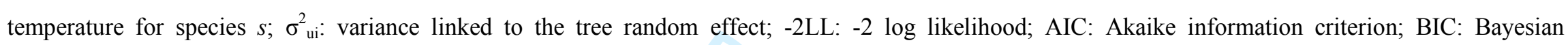
information criterion.

\begin{tabular}{|l|l|l|l|l|l|l|l|l|l|l|l|l|l|l|l|}
\hline Modelling step & 1 & 2 & 3 & 4 & 5 & 6 & 7 & 8 & 9 & 10 & 11 & 12 & 13 & 14 & 15 \\
\hline Intercept & $\alpha_{\mathrm{s}}$ & $\alpha_{\mathrm{s}}$ & $\alpha_{\mathrm{s}}$ & $\alpha_{\mathrm{s}}$ & $\alpha_{\mathrm{s}}$ & $\alpha_{\mathrm{s}}$ & $\alpha_{\mathrm{s}}$ & $\alpha_{\mathrm{s}}$ & $\alpha_{\mathrm{s}}$ & $\alpha_{\mathrm{s}}$ & $\alpha_{\mathrm{s}}$ & $\alpha_{\mathrm{s}}$ & $\alpha_{\mathrm{s}}$ & $\alpha_{\mathrm{s}}$ & $\alpha_{\mathrm{s}}$ \\
\hline Intersp. competition & $\beta_{\mathrm{s}}$ & $\beta_{\mathrm{s}}$ & $\beta_{\mathrm{s}}$ & $\beta_{\mathrm{s}}$ & $\beta_{\mathrm{s}}$ & $\beta_{\mathrm{s}}$ & $\beta_{\mathrm{s}}$ & $\beta_{\mathrm{s}}$ & $\beta_{\mathrm{s}}$ & $\beta_{\mathrm{s}}$ & $\beta_{\mathrm{s}}$ & $\beta_{\mathrm{s}}$ & $\beta_{\mathrm{s}}$ & $\beta_{\mathrm{s}}$ & $\beta_{\mathrm{s}}$ \\
\hline Intrasp. competition & $\gamma_{\mathrm{s}}$ & $\gamma_{\mathrm{s}}$ & $\gamma_{\mathrm{s}}$ & $\gamma_{\mathrm{s}}$ & $\gamma_{\mathrm{s}}$ & $\gamma_{\mathrm{s}}$ & $\gamma_{\mathrm{s}}$ & $\gamma_{\mathrm{s}}$ & $\gamma_{\mathrm{s}}$ & $\gamma_{\mathrm{s}}$ & $\gamma_{\mathrm{s}}$ & $\gamma_{\mathrm{s}}$ & $\gamma_{\mathrm{s}}$ & $\gamma_{\mathrm{s}}$ & $\gamma_{\mathrm{s}}$ \\
\hline dbh $_{\mathrm{i}}$ & $\theta_{\mathrm{s}}$ & - & - & - & - & - & - & - & - & - & - & - & - & - & - \\
\hline $\mathrm{T}_{\text {max }}$ & - & - & $\mu_{\mathrm{s}}$ & - & - & - & - & - & - & - & - & - & - & - & - \\
\hline $\mathrm{T}_{\mathrm{av}}$ & - & - & - & $\mu_{\mathrm{s}}$ & $\mu_{\mathrm{s}}$ & $\mu_{\mathrm{s}}$ & $\mu_{\mathrm{s}}$ & $\mu_{\mathrm{s}}$ & $\mu_{\mathrm{s}}$ & $\mu_{\mathrm{s}}$ & $\mu_{\mathrm{s}}$ & $\mu_{\mathrm{s}}$ & $\mu_{\mathrm{s}}$ & $\mu_{\mathrm{s}}$ & $\mu_{\mathrm{s}}$ \\
\hline Frost effect & - & - & - & - & $\varphi$ & - & - & - & - & - & - & - & - & - & - \\
\hline Drought occurrence & - & - & - & - & - & $\lambda$ & $\lambda$ & $\lambda$ & $\lambda$ & $\lambda$ & $\lambda_{\mathrm{s}}$ & $\lambda$ & $\lambda_{\mathrm{s}}$ & $\lambda_{\mathrm{s}}$ & $\lambda_{\mathrm{s}}$ \\
\hline Drought effect & - & - & - & - & - & - & $\delta$ & $\delta$ & $\delta$ & $\delta_{\mathrm{s}}$ & $\delta$ & $\delta_{\mathrm{s}}$ & $\delta$ & $\delta_{\mathrm{s}}$ & $\delta_{\mathrm{s}}$ \\
\hline Thermal amplitude & - & - & $\sigma^{2}$ & $\sigma^{2}$ & $\sigma^{2}$ & $\sigma^{2}$ & $\sigma^{2}$ & $\sigma^{2}$ & $\sigma_{\mathrm{s}}^{2}$ & $\sigma^{2}$ & $\sigma^{2}$ & $\sigma_{\mathrm{s}}^{2}$ & $\sigma_{\mathrm{s}}^{2}$ & $\sigma^{2}$ & $\sigma_{\mathrm{s}}^{2}$ \\
\hline Random tree effect & - & - & - & - & - & - & - & $\sigma_{\mathrm{ui}}^{2}$ & $\sigma_{\mathrm{ui}}^{2}$ & $\sigma_{\mathrm{ui}}^{2}$ & $\sigma_{\mathrm{ui}}^{2}$ & $\sigma_{\mathrm{ui}}^{2}$ & $\sigma_{\mathrm{ui}}^{2}$ & $\sigma_{\mathrm{ui}}^{2}$ & $\sigma_{\mathrm{ui}}^{2}$ \\
\hline- -2LL & 10124 & 10134 & 9570 & 9500 & 9489 & 8942 & 8718 & 8668 & 8656 & 8663 & 8661 & 8650 & 8647 & 8660 & - \\
\hline AIC & 10150 & 10154 & 9598 & 9528 & 9519 & 8972 & 8750 & 8702 & 8694 & 8701 & 8699 & 8692 & 8689 & 8702 & - \\
\hline BIC & 10230 & 10215 & 9684 & 9614 & 9611 & 9063 & 8848 & 8737 & 8733 & 8741 & 8738 & 8735 & 8733 & 8745 & - \\
\hline
\end{tabular}


Table 4. Summary of parameter estimates for the definitive model [12], where subscripts: $1=P$. pinea, $2=Q$. ilex, $3=J$. thurifera.$\alpha$ is the intercept for species $1,2,3 ; \beta$ is the parameter associated to interspecific competition for species $1,2,3 ; \gamma$ is the parameter associated to intraspecific competition for species $1,2,3 ; \delta$ is the parameter linked to the drought effect on species $1,2,3 ; \lambda$ is the parameter related to drought occurrence; $\mu$ represents the optimum daily average temperature for species $1,2,3$; $\sigma^{2}$ stands for the variance of the scaled normally distributed response of secondary growth to daily average temperature for species $1,2,3 ; \sigma_{\text {ui }}^{2}$ is the variance linked to the tree random effect.

\begin{tabular}{|llllll|}
\hline Parameter & Estimate & Stand. error & Df & $t$-Value & $p$-Value \\
\hline$\alpha_{1}$ & 3.5498 & 0.5647 & 57 & 6.29 & $<0.001$ \\
$\alpha_{2}$ & 2.0815 & 0.6622 & 57 & 3.14 & 0.003 \\
$\alpha_{3}$ & 1.9852 & 0.3492 & 57 & 5.69 & $<0.001$ \\
$\beta_{1}$ & -0.0989 & 0.1555 & 57 & -0.64 & 0.527 \\
$\beta_{2}$ & -0.0960 & 0.0442 & 57 & -2.17 & 0.034 \\
$\beta_{3}$ & -0.0545 & 0.0278 & 57 & -1.96 & 0.055 \\
$\gamma_{1}$ & -0.1692 & 0.0343 & 57 & -4.94 & $<0.001$ \\
$\gamma_{2}$ & 0.1000 & 0.1201 & 57 & 0.83 & 0.409 \\
$\gamma_{3}$ & -0.3425 & 0.1281 & 57 & -2.67 & 0.010 \\
$\delta_{1}$ & -0.1382 & 0.0256 & 57 & -5.40 & $<0.001$ \\
$\delta_{2}$ & -0.2559 & 0.0871 & 57 & -2.94 & 0.005 \\
$\delta_{3}$ & -0.1123 & 0.0215 & 57 & -5.22 & $<0.001$ \\
$\lambda$ & -0.6390 & 0.1136 & 57 & -5.62 & $<0.001$ \\
$\mu_{1}$ & 16.3750 & 0.3871 & 57 & 42.30 & $<0.001$ \\
$\mu_{2}$ & 31.9969 & 4.3007 & 57 & 7.44 & $<0.001$ \\
$\mu_{3}$ & 17.7550 & 0.5837 & 57 & 30.42 & $<0.001$ \\
$\sigma^{2}{ }_{1}$ & 64.7046 & 7.5925 & 57 & 8.52 & $<0.001$ \\
$\sigma_{2}^{2}$ & 210.3400 & 64.1181 & 57 & 3.28 & 0.002 \\
$\sigma_{3}^{2}$ & 67.4487 & 9.8537 & 57 & 6.84 & $<0.001$ \\
$\sigma^{2}{ }_{n i}$ & 0.1731 & 0.0666 & 57 & 2.60 & 0.012 \\
\hline
\end{tabular}


Table 5. Goodness-of-fit statistics calculated for different levels of grouping. Ê: estimated mean error; P-Values calculated under the null hypothesis $\mathrm{H}_{0}$ : $\mathrm{E}=0$; $\widehat{\mathrm{RMSE}}$ : estimated root mean square error; $\widehat{\mathrm{MEF}}$ : estimated modelling efficiency; $\mathrm{n}$ : Amount of girth increment observations by level of grouping; Pp: P. pinea; Qi: Q. ilex subsp. ballota; Jt: J. thurifera; LDP: low density plot; HDP: high density plot. Period evaluated May 2012 to April 2015.

\begin{tabular}{|c|c|c|c|c|c|c|}
\hline Scale & Level of grouping & $\hat{\mathrm{E}}$ & P-Value & $\widehat{\widehat{\mathrm{RMSE}}}$ & $\widehat{\overline{\mathrm{MEF}}}$ & $\mathrm{n}$ \\
\hline Whole & & 0.0092 & 0.445 & 0.694 & $33.4 \%$ & 3306 \\
\hline \multirow[t]{3}{*}{ Species } & $\mathrm{Pp}$ & 0.0320 & 0.267 & 0.997 & $25.1 \%$ & 1197 \\
\hline & Qi & 0.0023 & 0.865 & 0.363 & $39.2 \%$ & 741 \\
\hline & $\mathrm{Jt}$ & -0.0069 & 0.588 & 0.473 & $37.5 \%$ & 1368 \\
\hline \multirow[t]{2}{*}{ Plot } & LDP & 0.0341 & 0.114 & 0.876 & $25.6 \%$ & 1653 \\
\hline & HDP & -0.0156 & 0.153 & 0.444 & $49.8 \%$ & 1653 \\
\hline \multirow[t]{6}{*}{ Plot x Species } & $\mathrm{Pp}-\mathrm{LDP}$ & 0.1128 & 0.064 & 1.379 & $11.7 \%$ & 513 \\
\hline & Qi - LDP & 0.0083 & 0.668 & 0.414 & $38.6 \%$ & 456 \\
\hline & $\mathrm{Jt}-\mathrm{LDP}$ & -0.0078 & 0.715 & 0.559 & $30.7 \%$ & 684 \\
\hline & $\mathrm{Pp}-\mathrm{HDP}$ & -0.0286 & 0.181 & 0.559 & $47.4 \%$ & 684 \\
\hline & Qi - HDP & -0.0074 & 0.633 & 0.262 & $35.4 \%$ & 285 \\
\hline & $\mathrm{Jt}-\mathrm{HDP}$ & -0.0060 & 0.668 & 0.368 & $47.0 \%$ & 684 \\
\hline
\end{tabular}


Table 6. Goodness-of-fit statistics over the cumulative girth increment for the 58 trees studied. $\hat{E}$ : estimated mean error; P-Values calculated under the null hypothesis $\mathrm{H}_{0}: \mathrm{E}=0$; $\widehat{\mathrm{RMSE}}$ : estimated root mean square error; $\widehat{\mathrm{MEF}}$ : estimated modelling efficiency; $\mathrm{n}$ : number of trees. Period evaluated May 2012 to April 2015.

\begin{tabular}{|ccccccc|}
\hline Scale & Level & $\hat{\mathrm{E}}$ & P-Value & $\widehat{\text { RMSE }}$ & $\widehat{\mathrm{MEF}}$ & $\mathrm{n}$ \\
\hline \multirow{2}{*}{ Whole } & 0.5351 & 0.386 & 4.653 & $92.6 \%$ & 58 \\
\hline \multirow{2}{*}{ Species } & P. pinea & 1.8369 & 0.183 & 6.235 & $85.5 \%$ & 21 \\
& Q. ilex & 0.1356 & 0.770 & 1.575 & $93.8 \%$ & 13 \\
& J. thurifera & -0.3876 & 0.655 & 4.119 & $96.2 \%$ & 24 \\
\hline \multirow{2}{*}{ Plot } & Low density & 1.9529 & 0.076 & 5.929 & $90.8 \%$ & 29 \\
& High density & -0.8827 & 0.096 & 2.853 & $93.3 \%$ & 29 \\
\hline
\end{tabular}


Table 7. Summary of model validation with annual radial increment data. n: number of trees sampled for the validation, n-sig: number of trees with a significant positive correlation between observed annual radial increment (obtained from cores and cross section slices) and predicted annual girth increment (obtained through the model); Ave-r: average value of the Pearson's correlation coefficient for the observed significant correlation; Max-r: maximum value of the Pearson's correlation coefficient. Validation time period: 1997-2011.

\begin{tabular}{|c|c|c|c|c|c|c|c|c|}
\hline \multirow{2}{*}{ Species } & \multicolumn{4}{|c|}{ Low density plot } & \multicolumn{4}{c|}{ High density plot } \\
\cline { 2 - 9 } & $\mathrm{n}$ & $\mathrm{n}$-sig & Ave-r & Max-r & $\mathrm{n}$ & n-sig & Ave-r & Max-r \\
\hline P. pinea & 24 & 23 & 0.4007 & 0.6262 & 24 & 22 & 0.4761 & 0.6721 \\
\hline Q. ilex & 2 & 1 & 0.4111 & 0.4111 & 2 & 2 & 0.4000 & 0.5736 \\
\hline J. thurifera & 7 & 7 & 0.5497 & 0.7474 & 8 & 8 & 0.4248 & 0.6827 \\
\hline
\end{tabular}




\section{Figure captions}

Fig. 1. Average trajectories for the observed (solid lines) and predicted (dashed lines) girth increment values for the three species involved (Pp - P. pinea, Qi-Q. ilex, Jt-J. thurifera).

a) High density plot. b) Low density plot.

Fig. 2. Effects on secondary growth of the different covariates included in the definitive model. a) Optimum daily average temperature with different thermal amplitudes by species. b) Drought effect simulation considering initial water reserve $\left(W R_{0}\right)=0$ and a single precipitation event on the first day of the simulation, where $P_{1}=5 \mathrm{~mm}$.

Fig. 3. Observed vs. predicted cumulative girth increment values of individual trees shown by species at the end of the study period (1 062 days). a) P. pinea. b) Q. ilex. c) J. thurifera. Solid lines refer to the 1:1 line. Remarked are those P. pinea trees responsible for the bias in the low density plot. LDP: low density plot; HDP: high density plot.

Fig. 4. Observed values of annual radial increment (solid lines) vs predicted values of girth increment (dashed lines) for the randomly selected a) tree 1018 (P. pinea, low density plot), b) tree 1813 (Q. ilex, high density plot) and c) tree 1115 (J. thurifera, low density plot).

Fig. 5. Cumulative girth increment by species during the main growth period under current climate conditions (2014) and future climate forecasts (2075). 2075 growth projections calculated with an increment of $4.5{ }^{\circ} \mathrm{C}$ on average temperature, and a decrement of $30 \%$ in annual rainfall (climate model ACCESS 1-0). 


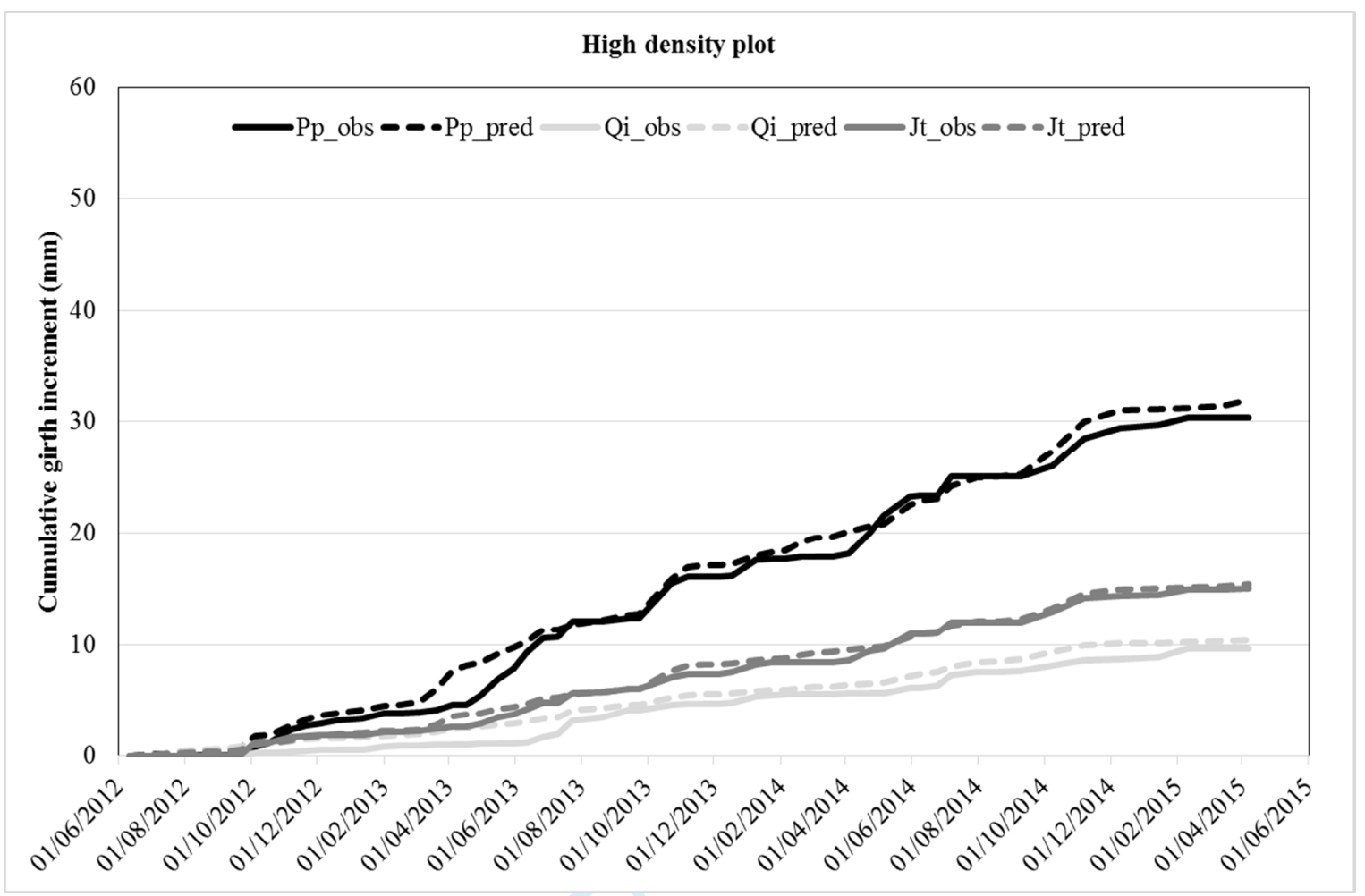

Fig. 1a.

Low density plot

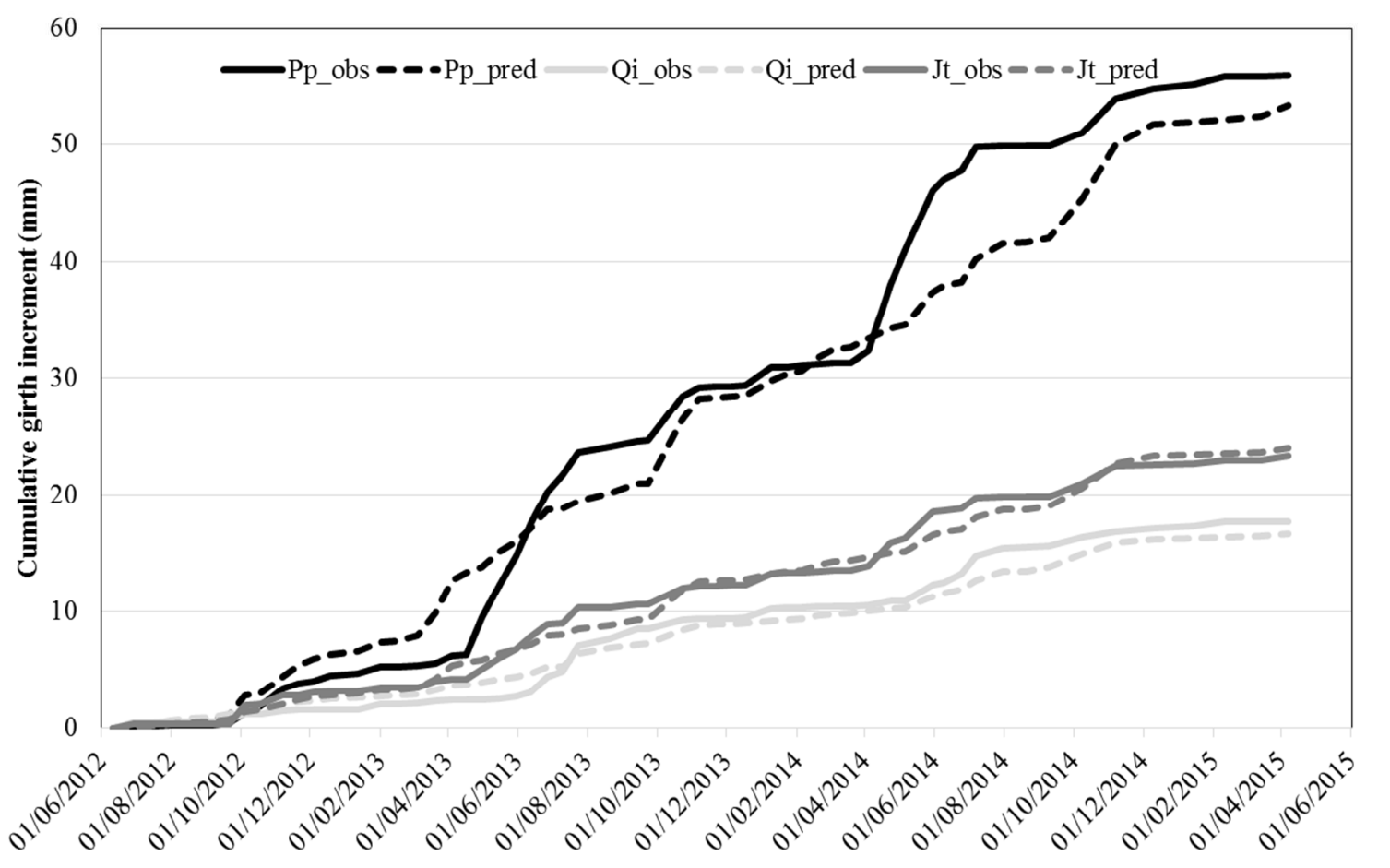

Fig. $1 b$. 


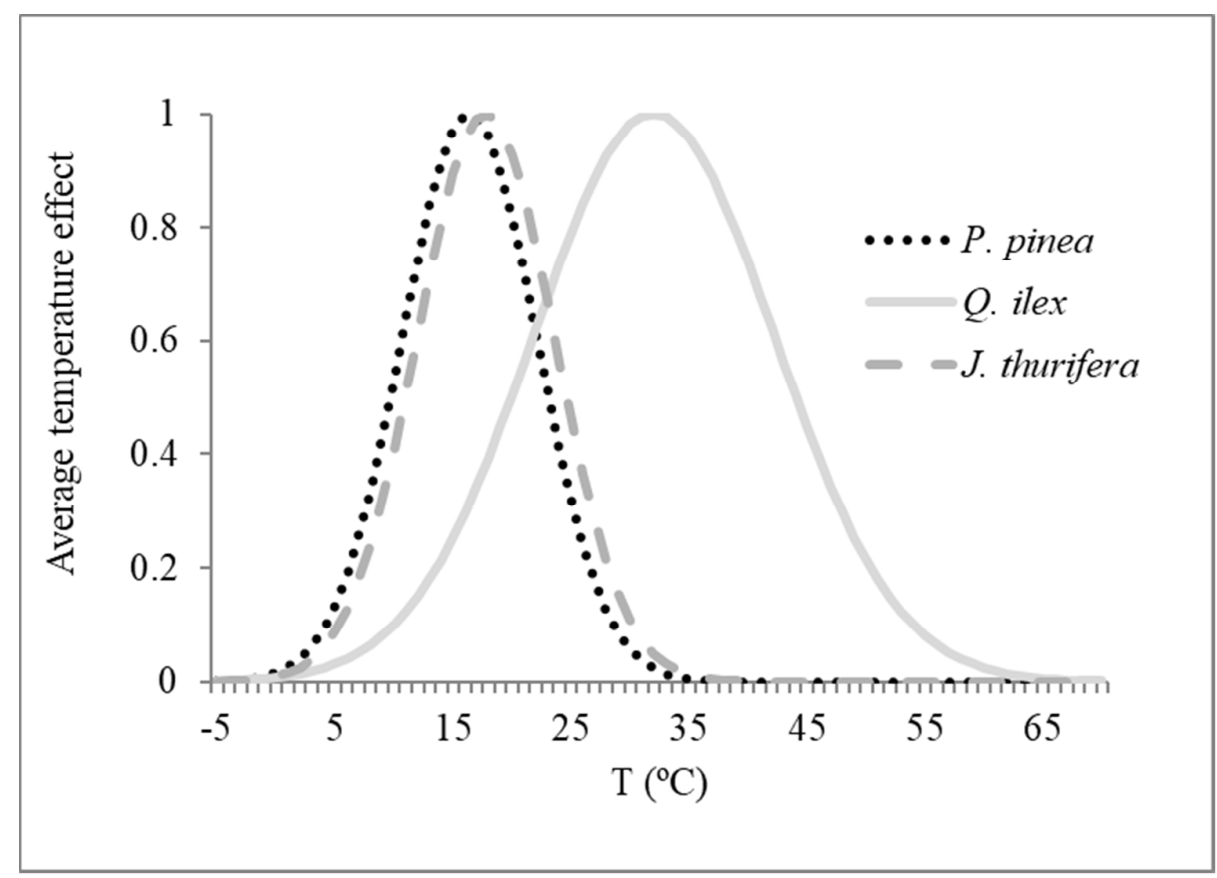

Fig. $2 a$.

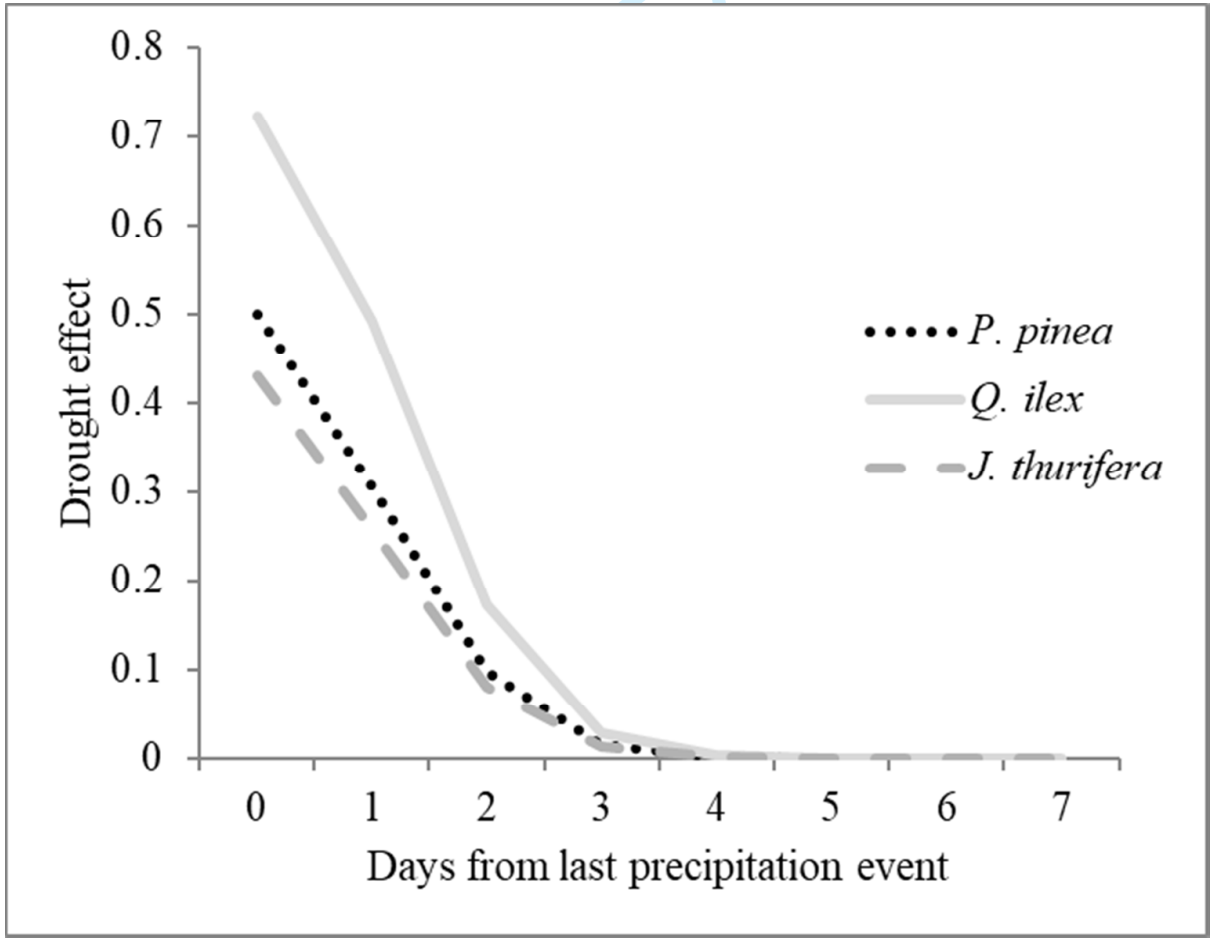

Fig. $2 b$. 


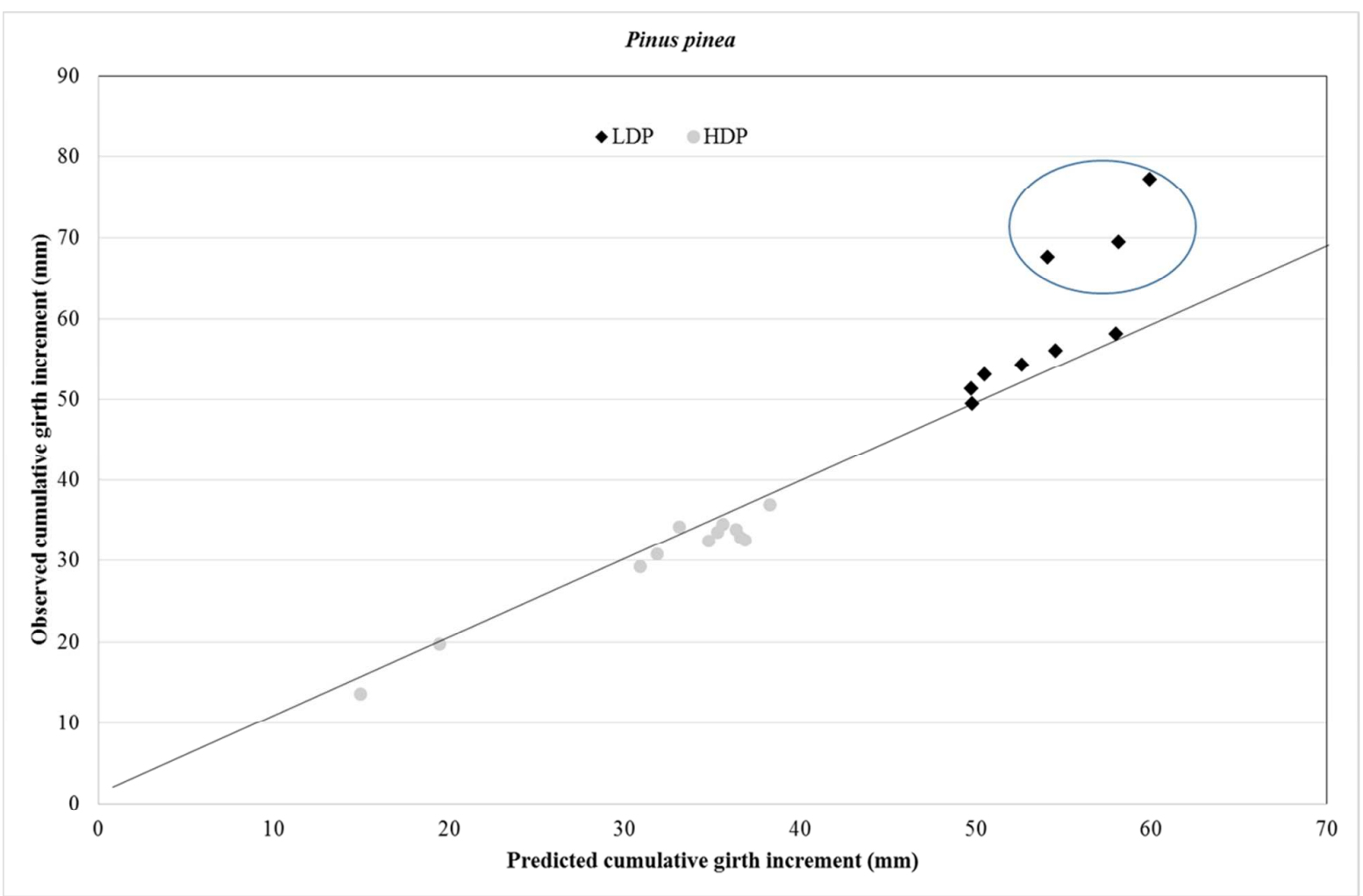

Fig. 3a.

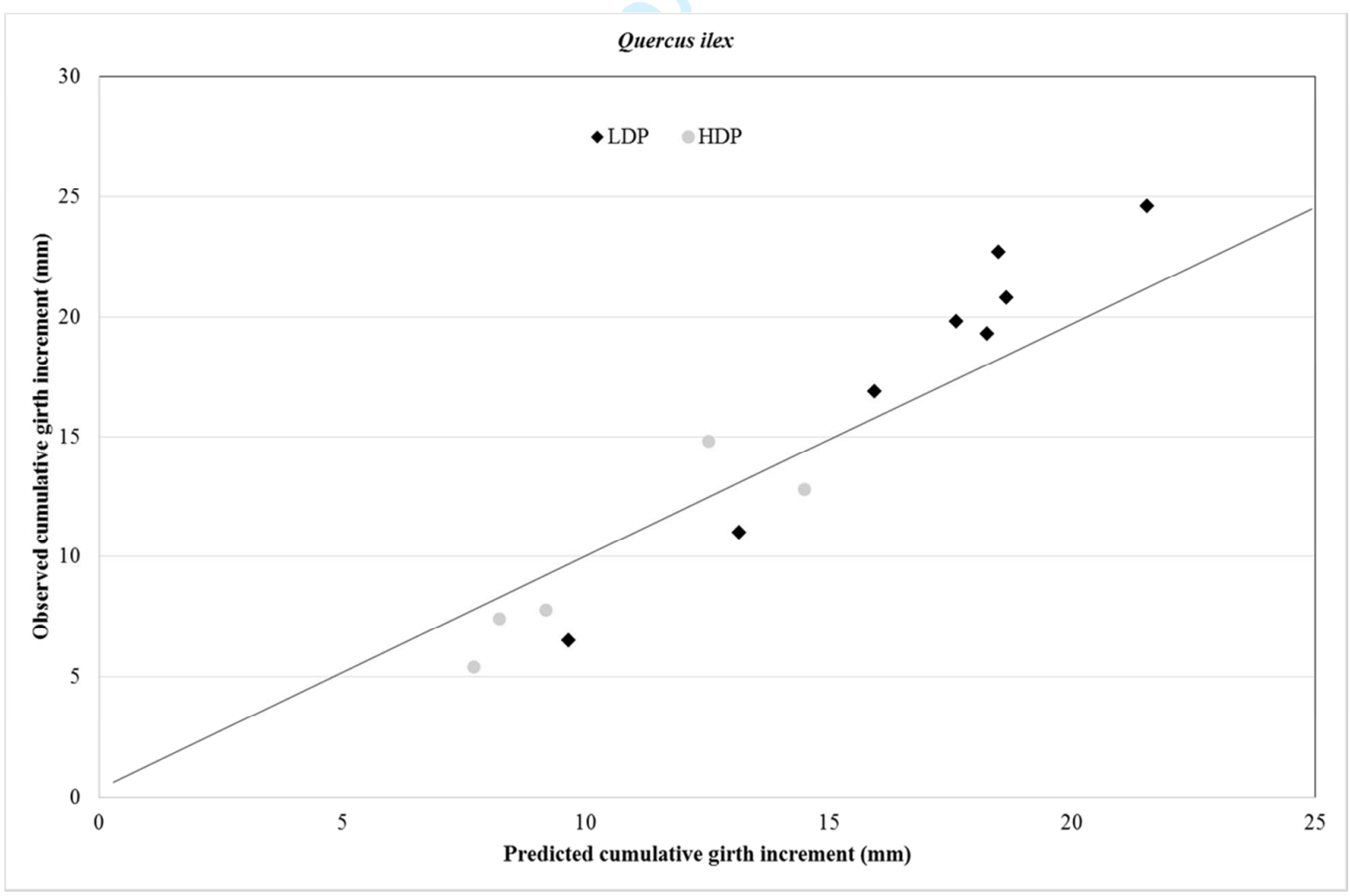

Fig. $3 b$. 


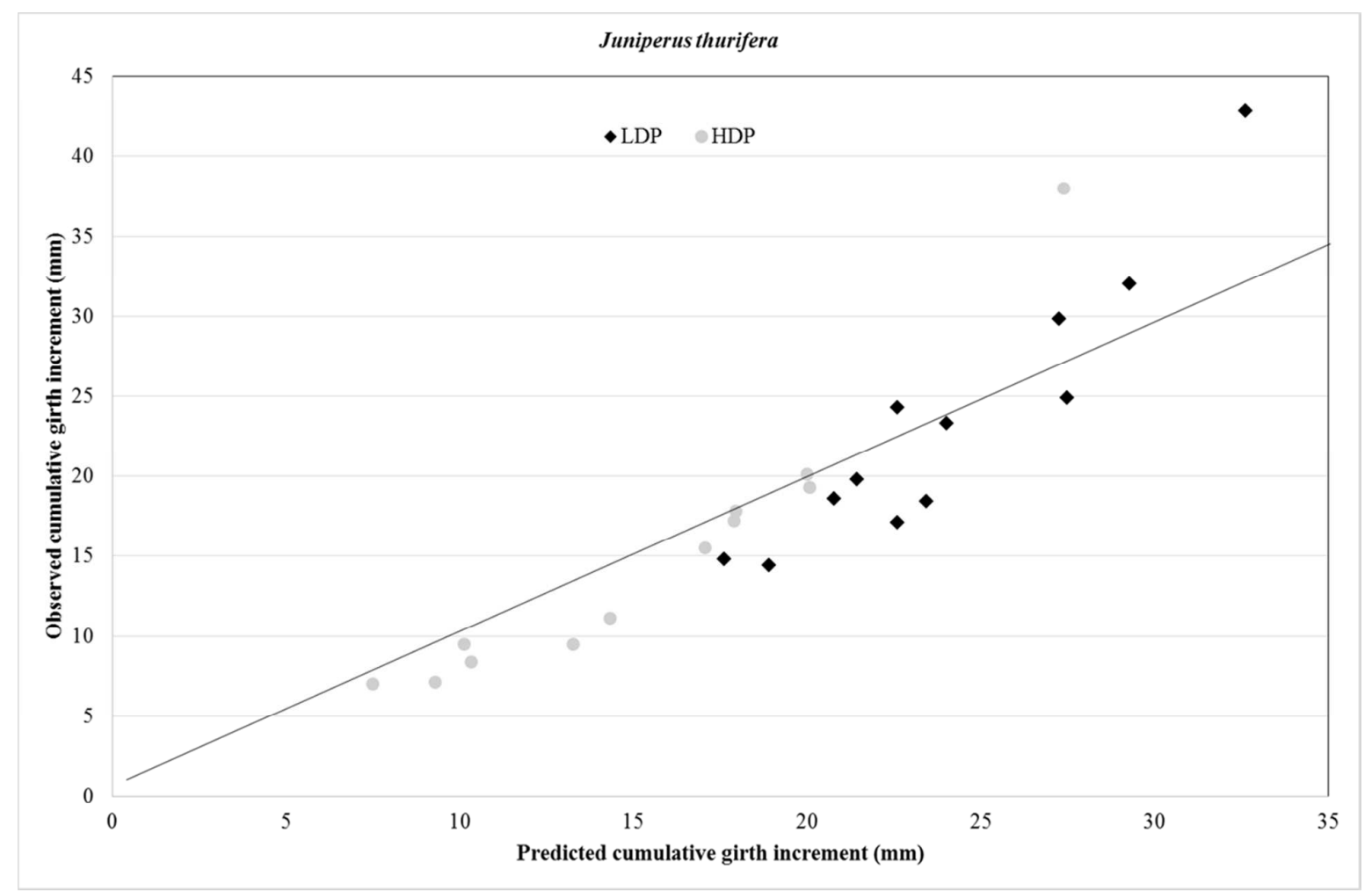

Fig. $3 c$. 


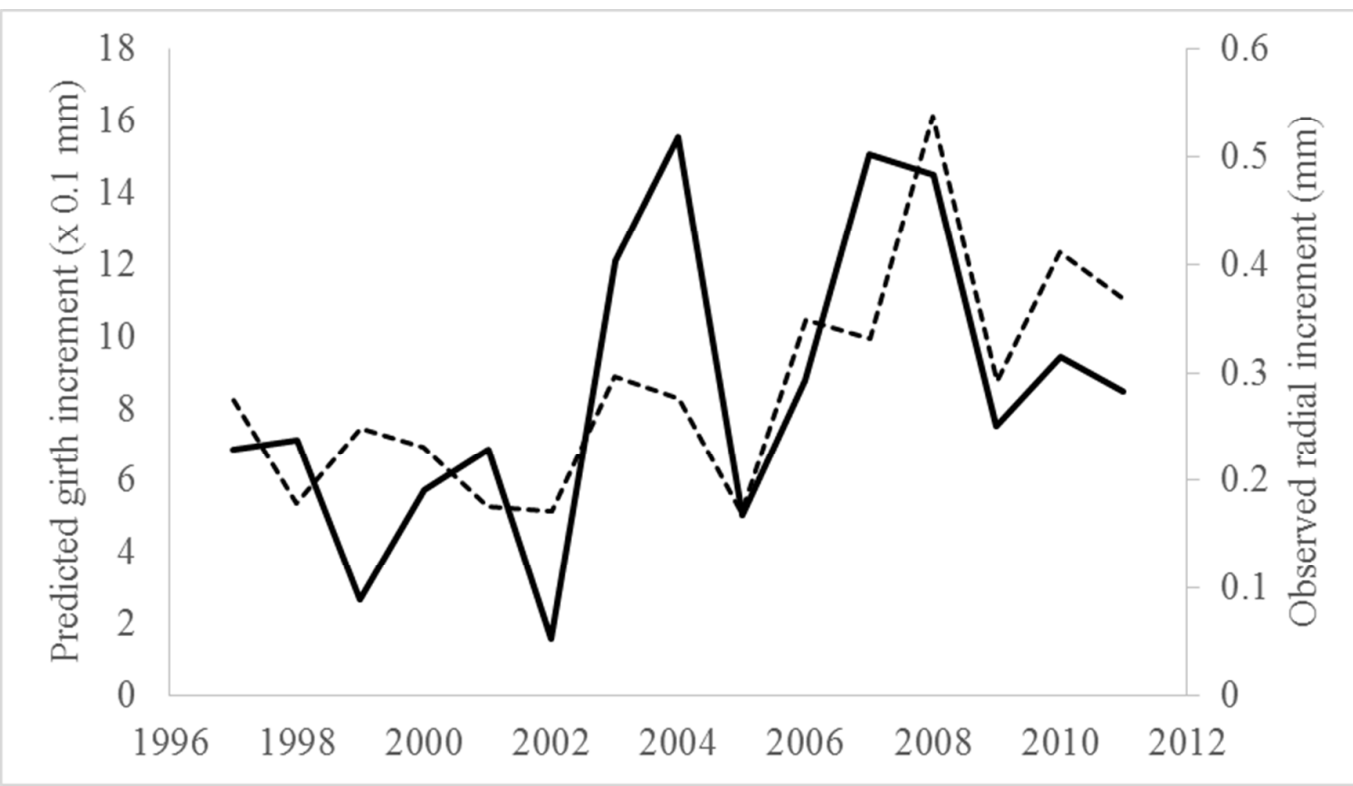

Fig. $4 a$.

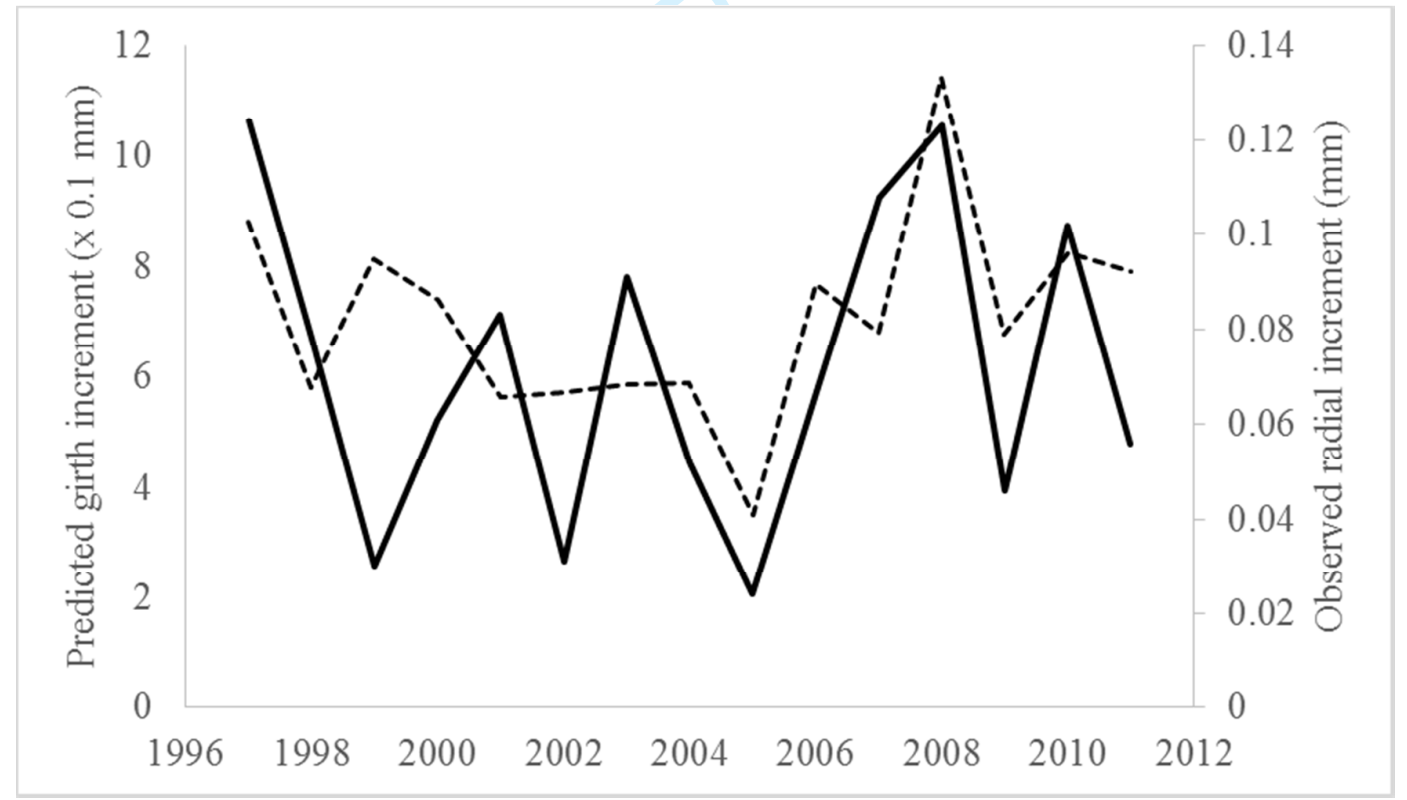

Fig. $4 b$. 


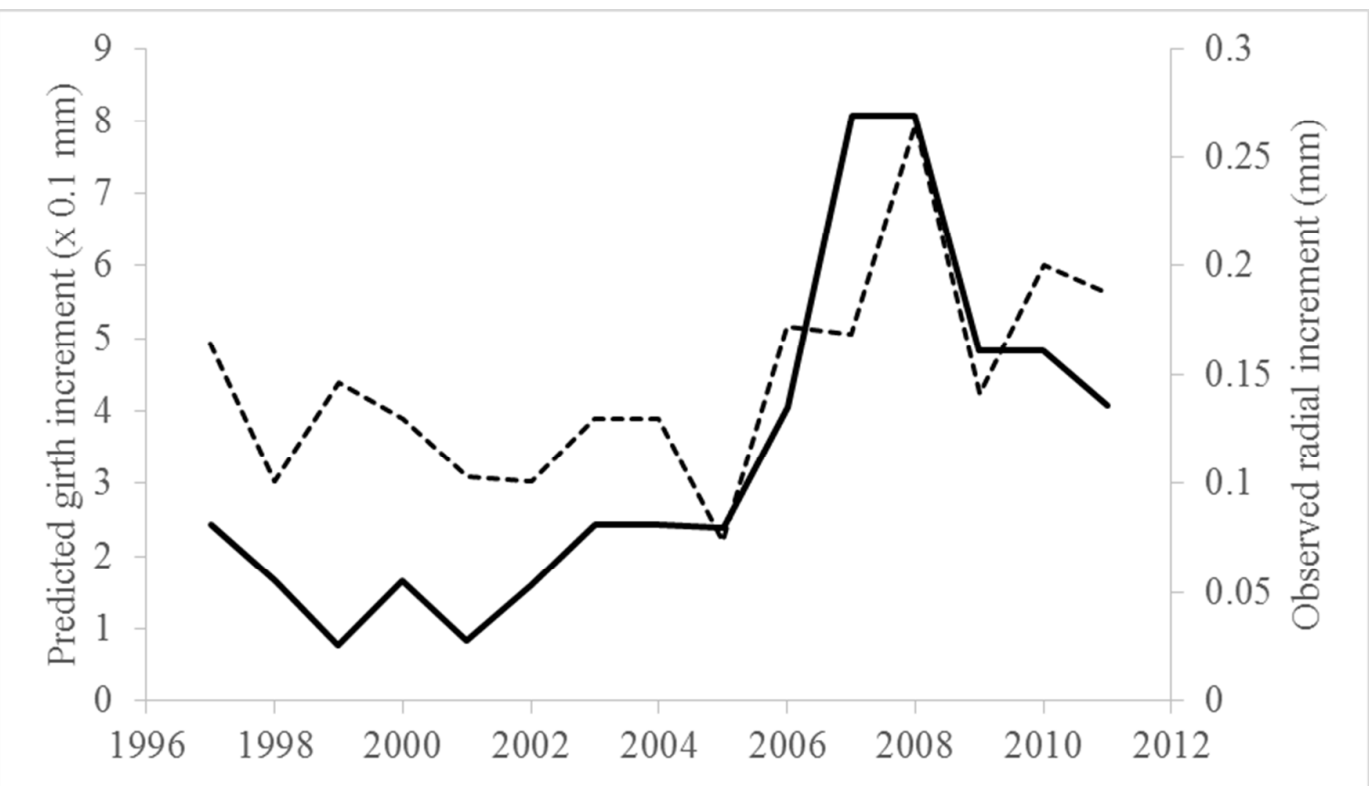

Fig. 4c. 


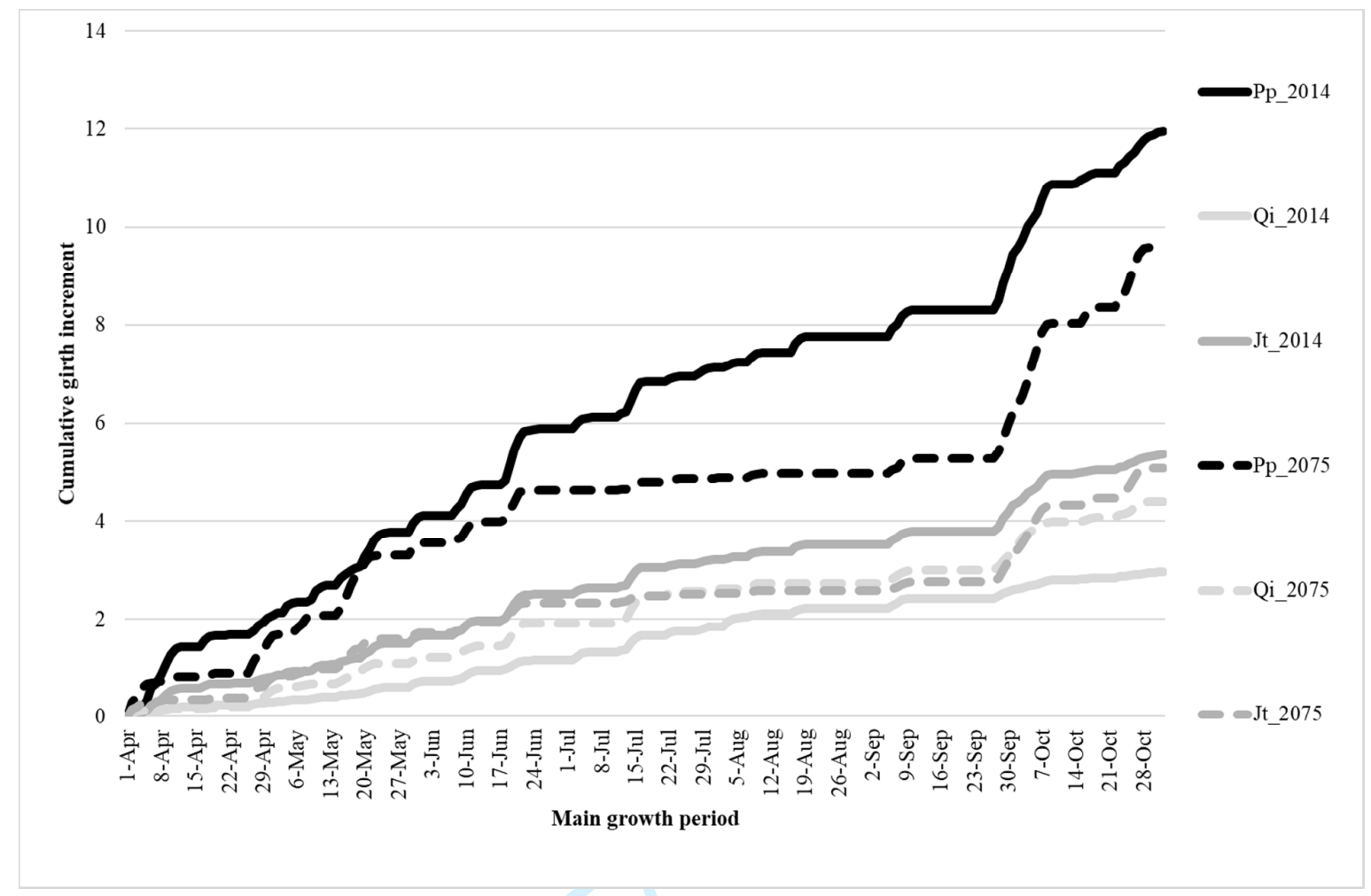

Fig. 5 


\section{Appendix. Distance dependent competition indices}

2 We used the distance dependent competition indices developed by Bella (1971) and later modified by

3 Tomé and Burhart (1989) to define intraspecific and interspecific interactions between the trees of the

4 area of study. They are area overlap indices (AOI) which calculate an influence zone around each

5 subject tree $\left(\mathrm{ZA}_{\mathrm{i}}\right)$, where $\mathrm{ZA}_{\mathrm{i}}$ dimension is related to tree size:

$6 \quad A O I_{i}=\sum_{j=1}^{n} \frac{Z O_{i q}}{Z A_{i}} \cdot\left(\frac{d b h_{q}}{d b h_{i}}\right)^{k}$

7 These competition indices sum over all tree contestants for a subject tree i (n, being the number of tree

8 competitors whose area of influence intersects that of the subject tree i) the proportion of $\mathrm{ZA}_{\mathrm{i}}$ that is

9 included in the influence zone of each competitor $\left(\mathrm{ZO}_{\mathrm{iq}}\right)$. These proportions are weighed by the

10 term $\left(\frac{d b h_{q}}{d b h_{i}}\right)^{k}$, where $d b h_{\mathrm{i}}$ and $\mathrm{dbh}_{\mathrm{q}}$ are diameter at breast height of the subject tree $i$ and of the competitor tree $\mathrm{q}$ respectively; $\mathrm{k}$ is a power factor. Among the different possible combinations between $\mathrm{k}$ and radius of influence zone area for each species, $\mathrm{R}$, we selected $\mathrm{R}$ equal to 30 times $\mathrm{dbh}$ for intraspecific competition and 40 times dbh for interspecific competition. Concerning the weighting factor $\mathrm{k}$, we set $\mathrm{k}=1$ for intraspecific interactions, indicating asymmetry on competition, and $\mathrm{k}=0$ for interspecific interactions, pointing to symmetric effects between species. This AOI combination has already proved to accurately describe the effect of competition on growth in these Pinus pinea admixtures in previous studies of the group. For more information on the use of this family of indices in mixtures see de-Dios-García et al. (2015).

Bella, I.E. 1971 A new competition model for individual trees. For. Sci. 17(3), pp.364-372.

De-Dios-García, J., Pardos, M. \& Calama, R. 2015 Interannual variability in competitive effects in mixed and monospecific forests of Mediterranean stone pine. For. Ecol. Manage. 358, pp.230239.

Tomé, M. \& Burkhart, H.E. 1989 Distance-dependent competition measures for predicting growth of individual trees. For. Sci. 35(3), pp.816-831. 